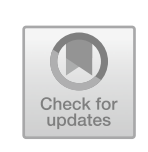

\title{
Pirate Narratives and the Revolutionary Atlantic in the Early Republic and the Antebellum Period
}

\subsection{Pirate Narratives \\ AND THE Romance of THE REvOlUtion}

The early American Republic and the first half of the nineteenth century were obsessed with what Henry Steele Commager ([1965] 1967) famously called the "search for a usable past" (in reference to literary critic Van Wyck Brooks's 1918 essay "On Creating a Usable Past") and the cultural construction of the "imagined community" (B. Anderson) of U.S.-American citizens to create and consolidate a national identity. In both literature and the wider field of cultural production, including festivities and a memorial culture, American history and its accompanying mythologies became useful resources for the creation of a national culture and literature which sought to distance itself from a British heritage. On the one hand, writers of literature reverted to the specific American theme of cultural contact with indigenous populations (whose extinction was euphemized as the downfall of the 'noble savage,' doomed by an allegedly superior civilization, most prominently in James Fenimore Cooper's Leatherstocking Tales); on the other, the evocation of the American Revolution as well as her maritime strength in commerce and war was a standard tool, especially in the historical romance, to cement heroic narratives of freedom-fighting Americans and to activate, rejuvenate, and actualize a shared memory. The entire post-revolutionary period, according to Daniel Williams, was marked by a celebration of

(C) The Author(s) 2020

A. Ganser, Crisis and Legitimacy in Atlantic American Narratives of Piracy, Maritime Literature and Culture, https://doi.org/10.1007/978-3-030-43623-0_3 
defiance and autonomy, specific qualities of subsequent U.S.-American outlaw masculinities:

After the Revolution, after the country had itself defied authority, descriptions of deviant and defiant individuals became especially popular in American literature, and the criminal ... became both hero and anti-hero, both epitome and parody of the American character. As a literary figure, the criminal moved from Puritan condemnation to post-Revolutionary celebration. ... Self-determination, self-reliance and self initiative became socially celebrated ideals. Defiance of authority became pervasive, almost institutionalized. (Williams 1983, 6; 13)

"In a new nation in a New World," Williams continues, such outlaw figures "represented new possibilities for the individual. Living in a competitive society where money had replaced the traditional bonds among people, they quickly embraced the profit motive and accepted the vision of the self-made man" (17). In this context, it is perhaps no surprise that the pirate was nationalized and re-signified as a figure of popular identification, given his/her symbolic history of profiteering, selfstylization, and independence. David Reynolds calls such figures "likable criminal[s]," patriotic outlaws that had a special meaning in antebellum America, as the nation as a whole "was a justified pariah-a nation that had recently waged holy war against a foreign oppressor and that still felt the paradoxical spirit of optimism and militancy, progressivism and pugnaciousness. ... There was ... a ... democratic impulse to make heroes of those who lashed out angrily against what was viewed as deepening social corruption" $(1988,180-81)$. Paradoxically, it was the transnational potential of the pirate as the (male or sometimes female) hero of a historical romance, a figure beyond national belonging, which made her/him suitable for appropriation by various patriotic discourses; thus in the context of the early Republic the heroic English pirate is taken up and Americanized into a figure of liberty. In this way, $\mathrm{s} /$ he functions as a postcolonial foundational figure for the national imaginary and mythology: an outlaw figure whose illegitimacy is discursively transformed by its romanticization into a context of a legitimate break of rule.

However, the pirate as a figure of liberty is double-edged, evoking the foundational crisis of legality at the beginning of colonial emancipation as well as actual threats by (less romantic) pirates who were on the rise again after the War of 1812. The first half of the nineteenth 
century was marked by a number of crisis scenarios besides the War of 1812 against Great Britain; in addition, the sectional Nullification Crises over federal tariffs, the wars against Native American peoples, and both the budding slavery debates, leading to the Missouri Crisis in 1821, and the so-called woman question, steadily increasing in intensity toward the mid-century, troubled the early Republic. All of these shared a context of intense debate about the U.S. legal system and the appropriate kind of law in the young United States, especially concerning the role of the English common law tradition. As Charles Hansford Adams points out, these debates were significant for "the American dilemma" (Perry Miller) between self and community (1990, 2-3): "In the deliberations over what sort of country the United States would be, the nature of 'legal law' was perceived as crucial" (3) as "the American mind ... was marked by a search for legitimate 'parental' authorities" (10). ${ }^{1}$ The use of piracy in antebellum fiction hence also functioned as a way to articulate discussions about the character of "natural law" and how U.S.-American law could emulate it.

In the following, I am arguing that such critical scenarios of the early nineteenth century were rearticulated through the narration of revolutionary piracy and its legitimation in discourses of freedom and oppression. In the early popular national literature, the revolutionary pirate was turned into a romantic figure, paradoxically modeled upon the Byronic pirate (see Lord Byron's tale in verse "The Corsair," 1814, and its "new vision of the pirate, not as a bloodthirsty criminal, but as superb embodiment of romantic freedom, self-assertion, and alienation" [Th. and M. Philbrick 1991, xx]), while Byron's poem marks another instance of transatlantic cultural crossings, given that Byron had been inspired by reports about the Florida pirate-smuggler and slaver Jean Lafitte (Rennie 2013, 128). In these narratives of the Revolution, the dissociation from Great Britain, which was again on the daily agenda with a new war and could not be taken for granted (e.g., when New England coastal towns sympathized with the official enemy), was accomplished by evoking the pirate: wresting her/him from British hands-after all, pirates like Sir Francis Drake had long become popular foundational figures in the British pantheon-and appropriating her/him as an ideal type of the patriotic outlaw, who risked (and at times sacrificed) his/her life for a just and victorious cause, as in Cooper's The Red Rover (this appropriation is shadowed concurrently in formal terms, as Cooper attempted to improve Sir Walter Scott's model of the historical romance). As my 
readings of the two arguably most popular pirate tales of the first half of the nineteenth century-Cooper's Rover and Maturin Murray Ballou's novelette Fanny Campbell: The Female Pirate Captain. A Tale of the Revolution (1844/1845)-will show, historical romances in early American literature that thematized the legitimacy of the Revolution appropriated the romantic concept of piracy — albeit with twists and modulations - in order to debate antebellum issues of legitimacy, authority, and equality with regard to race, class, and gender. ${ }^{2}$

For James Fenimore Cooper, who was keenly interested in the postrevolutionary legal debates, the pirate anticipated the anti-legalism soon to be advocated by the transcendentalists and other U.S. intellectuals (a position that saw the law as undemocratic and was defeated with the acceptance and subsequent Americanization of the English legal heritage). Cooper's Red Rover personifies the conviction, brought forth in the Declaration of Independence "that, though the Revolution was ostensibly a rebellion against established order, it was necessitated and justified by insufferable violations of existing laws and rights and sanctified by the 'laws of Nature and of Nature's God'-laws inherent ... in a cosmic moral order" (Beard 1976, 86). In the end, the revolutionary Rover is reintegrated into society; thus the narrative first celebrates the maritime outlaw and then tames him into a figure of the revolutionary past.

The national appropriation of a romantic pirate figure who could be integrated, eventually, into the community, also reverberated in the arena of narrating gender roles, which were in a phase of critical transformation throughout the nineteenth century. The recourse to the Revolution in popular literature called upon enlightenment models of revolutionary femininity and the subsequent "Republican mother," which in turn inspired an emergent 'first wave' of feminism. Yet while the patriotic woman of the nineteenth century, as I am arguing in my reading of Fanny Campbell, enjoys recalling her adventurous, revolutionary past, she accepts that the times have changed and a new model of femininity is the order of the day. The former revolutionary heroine, a patriotic female pirate, is domesticated in such popular tales in order to make palpable to its plethora of female readers a more passive image of womanhood and to girdle the emergent feminism of the 1840s, which radically questioned the cardinal virtues of what historian Barbara Welter called "the cult of true womanhood": piety, purity, domesticity, and submissiveness. As figures of ambivalence, however, literary pirates like the Red Rover 
or Fanny Campbell disturbed rather than backed this neat transformation from revolutionary pirate to law-abiding citizen.

\subsection{Crises of Authority and National Identity in James Fenimore CoOper's Red Rover (i827)}

\subsubsection{Cooper's Maritime Nationalism}

James Fenimore Cooper's early work-including his trilogy of sea tales (The Pilot, 1824; The Red Rover, 1827; The Water-Witch, 1830)—was primarily concerned with the dramatization of the process of separation between Great Britain and her American colonies, and of "the slow awakening of an American national consciousness" (Philbrick 1961, 58). Cooper's sea tales, the first volumes of maritime fiction by an American author (Blum 2008, 71), stage this process on the Atlantic Ocean, reverberating with Henry Nash Smith's ([1950] 2009, 12) observation that a military and economic command of the seas was one of the two early conceptions of a U.S.-American Empire (the other being westward expansion, which became dominant in the course of the nineteenth century). The idea of the young United States as a leading seafaring nation which, ideally, "carr[ied] the idea and the practice of individual liberty everywhere in the world" (Green 1978, 167), brought forth a maritime nationalism still prevalent in discourses about the United States' national identity and future destiny in the 1820s; in the field of literature, a plethora of nautical narratives published in the first half of the nineteenth century testifies to the idea that the American frontier was yet primarily imagined as maritime, inspired as the sea tales were by naval victories of the Revolution, against the French and the Barbary States, and of the War of 1812 , as well as by the rapid expansion of U.S.American overseas trade (Philbrick 1961, vii \& 1; Clohessy 2007; Bender 1990, 18). Cooper himself, in the second volume of Notions of the Americans (1828), held that "the tide of emigration, which has so long been flowing westward, must have its reflux ... . [T] he great outlet to the rest of the world, the path of adventure, and the only, at least the principal, theatre for military achievements open to the people of this country, is on the ocean" $(83,86) .^{3}$ Accordingly, Cooper "established the sea as a legitimate, indeed inevitable, landscape for literary historical fiction," as Hester Blum notes $(2008,74)$. In The Red Rover, Cooper's most 
popular sea tale, the titular Rover likewise imagines America in terms of its coasts and seas: "how many noble rivers pour their waters into the sea along this coast of which we have been speaking; how many wide and commodious havens abound there; or, how many sails whiten the ocean that are manned by men, who first drew breath on that spacious and peaceful soil'" (725).

Cooper scholarship largely agrees with the characterization of the "sea tales" as texts of maritime nationalism, following Thomas Philbrick's groundbreaking study James Fenimore Cooper and the Development of American Sea Fiction (1961), an analysis of maritime nationalist literature from Freneau and Royall Tyler to Charles Lenox Sargent's The Life of Alexander Smith (1819), Washington Irving's sketch "The Voyage" (1819) and Cooper, in which he established the term "maritime nationalism" (Philbrick 1961, ch. 1). More recently, the concept of maritime nationalism has been re-evaluated in a transatlantic context: Iglesias, for instance, argues that "Cooper's sea novels provide a broader conception of American literary nationalism and authorship conceived in terms of the transatlantic world, grasping the cultural tensions between America and Britain still driven by the unresolved conflicts after 1812" (2006, n.p.). In a similar vein, Sir Walter Scott's influence has been critically reframed ${ }^{4}$ : Kwame Anthony Appiah, drawing on George Dekker's seminal collection of essays James Fenimore Cooper: The American Scott (1967), ${ }^{5}$ does not dispute that Cooper's style is informed by Scott's popular romances, which were "amongst the most widely read and admired works of fiction in the United States in the first half of the nineteenth century" (1995, 281), but views Cooper's work as first and foremost paralleling Scott's in terms of its racist hierarchies and postcolonial nationalism (e.g., with regard to the construction of space, since Scott's romantic and masculinist notion of life on the Scottish borders was "easily transferred in imagination to the rigors of North American pioneer life"). Lawrence Buell suggests that Cooper's imperfect break from Scott "might be seen as a mark of the "colonized mind"' (1992, 422), but also highlights his imperialism, as he "played the postcolonial to the extent that he deferred to Scott's plot forms, but he played the imperialist to the extent that his own narratives reflected and perpetuated the romance of American expansionism" (435). I will contend throughout this chapter that Cooper's postcolonial appropriation of Scott happened in ways specific to the American historical situation, also and especially with regard to the significance of the pirate figure. 
Paradoxically, U.S.-American maritime nationalism constituted a continuation of England's national self-conception of the seventeenth and eighteenth centuries, and Cooper seems to have been fully aware of this (Green 1978, 168). It is manifest in Cooper's use of pirates in the sea tales as liminal and ambiguous figures of the past, who, on the one hand, recall British tradition and heritage-also qua literary renditions of Shakespeare, Defoe, Sir Walter Scott, or Lord Byron-and dramatize the American break-away from them on the other, by inventing a revolutionary pirate as a "justified pariah" (Reynolds 1988, 181) not unlike the United States. ${ }^{6}$ The invocation of the Revolution in Cooper's earliest novels, in this context, has been read as an attempt to "establish the conditions of a legitimate national authority, in which the claims of law and self could be balanced" (Adams 1988, 166), as, indeed, a utopia of law. As I argue in my reading of The Red Rover, Cooper's ambivalent use of the pirate dramatizes the critical search for a legal and legitimate national identity in the early Republic, as the figure of the Rover precipitates a crisis of law and authority by invoking more general questions of legitimacy: the (political and cultural) legitimacy of the American Revolution and U.S. independence, and, on a much subtler level, that of slavery and gender inequality.

\subsubsection{The Invention of Tradition: The Red Rover as Realist Romance}

Cooper wrote The Red Rover during his time in Paris as an improvement of his first nautical romance The Pilot, which, in turn, was conceived as a critical response to Scott's much-praised The Pirate (1822). Cooper resented Scott's "lubberly treatment of the nautical scenes" (Walker 1963, vi) and was convinced that his own knowledge and experience of the sea (including a chase by pirates off the coast of Portugal) would ensure more verisimilar nautical tales. Like The Pilot, he dedicated The Red Rover to his long-time naval friend and sea-going companion, Commodore William Branford Shubrick of the U.S. Navy, who had become his "nautical proofreader" (Blum 2008, 88). ${ }^{7}$ The 1827 preface elucidates Cooper's understanding of his literary ideal in nautical terms, claiming with a sense of irony that " $[\mathrm{t}]$ he true Augustan age of literature can never exist until works shall be as accurate, in their typography, as a 'log-book,' and as sententious, in their matter, as a 'watch-bill'” ([1828] 1991, 425). Both paratextual features-dedication and preface-work to 
assert Cooper's authority of experience as a writer of sea fiction, infusing Scott's model of the historical romance with a sense of "nautical realism" (Blum 2008, 72). ${ }^{8}$ In fact, Blum contends, Cooper's early work reflects an uneasy shift from romanticism to realism (the dominant mode of nautical fiction by the 1840s, as exemplified for example by Richard Henry Dana's Two Years before the Mast, 1840). In her reading, it still "misses the point of nautical realism" (72) compared to popular narratives written by common sailors at the time (whose use of first-person narration heavily influenced Cooper's later work), but the comparison is somewhat uneven, given that most sailors' accounts were not fictional.

Cooper's imperfect realism-especially his concern for precision and nautical detail, prime stylistic tools to render his historical inventions credible and convincing, to produce what Roland Barthes (1989) has termed "the effect of reality" - seems at odds with his use of the stock ingredients of romance: kidnappings, masquerades and deception, melodramatic family reunions and a romance plot, superstition, mystery, and supernatural elements as well as a sense of allegory. ${ }^{10}$ This poses a considerable predicament in the sea tales as well: "the fictional celebration of his doctrine of maritime nationalism demanded the exalted and ideal tone of romance; the known facts of American maritime history rendered such a tone absurd" (Philbrick 1961, 51). Egan suggests that the romance genre's general emphasis on strangeness rather than familiarity of experience and "the need to create a world rather than fit into one" (1995, 67) were in fact pivotal in the context of developing a U.S.-American literature as exceptional and new; at the same time, the political development of an American perspective also fostered a literary departure from established models of English narrative modes, developing a style of narration that Margaret Cohen has called "active description" (in contrast to omniscient narration; 2008, 75).

The only available solution for Cooper, it seems, was a recourse to the historical romance genre, inventing appropriate incidents and characters and embedding them in a general historical setting (Philbrick 1961, 51) while using a language that aimed at heightening said effect of reality; this solution echoes Winfried Fluck's characterization of the historical romance as a fundamentally hybrid genre that functioned as a "civilizing literary force" (in the Original "literarische Zivilisierungsinstanz," 1997, 107; my translation), combining the two genres of historiography and romance, one serious and instructive, the other sensational, popular, and low of status (also Campbell 2011, 20). Cooper's choice of the historical 
romance, initiated and popularized by Sir Walter Scott, is significant in the context of the invention of an American literary tradition as wellthough, as Frank and Mueller-Vollmer have observed, this was probably not really a question of choice, as Anglo-American writers who "wanted to develop distinctive literary traits" still had to "remain in close relation to the literature of Britain"; "[1]iterary Americanness was rather a question of how to place one's work in the cross-Atlantic reading culture so that it would make a difference" $(2000,182)$. After all, in the postcolonial context of the early Republic, American literature was not only written for U.S.-Americans, but also to establish a genuine American culture in an international, predominantly transatlantic arena in the context of a struggle for cultural recognition. The use of the historical romance for such national(ist) purposes perfectly suited this endeavor: as a widely popular "literary currency" (Cohen 2003, 481) across Europe and the Atlantic, it constituted an international phenomenon at the time (Frank and Mueller-Vollmer 2000, 177) that was nationalized by U.S.-American writers like Cooper, choosing distinctly American topics and subjects and using (albeit often awkwardly) vernacular American sociolects (apparently much praised by contemporary critics for being both humble and fiercely nationalistic; cf. Blum 2008, 78). ${ }^{11}$

Although by 1820 the historical romance had gained wide acceptance as a fictional form, "the viability of U.S.-American materials within that form remained a serious and debated question" (Dekker and Williams $1997,2)$ - thus the criticality of the genre in the struggle for a transatlantic recognition of American culture. Reviewers on both sides of the Atlantic used Cooper's work as a vehicle for considering this issue: is American culture sufficiently rich to support a historical romance, what are the materials best suited to the genre, and how should these materials be wrought for greatest effect? ${ }^{12}$ In the 1834 edition's preface, Cooper himself articulates this "problem," stating that "America is a country nearly without traditions, the few there are being commonly too familiar to be worked up in fiction" ([1828] 1991, 427) and thus voicing his "grievance ... that America's maritime past cannot provide the glorious subject matter ready-made in the British Royal Navy's rich annals" (Blum 2008, 77). America seemed too common and matter-of-fact to Cooper. The only exception, Cooper states in the preface to the 1850 Putnam edition (a reissue that responded to readers' craze for nautical fiction in the 1840s), were America's famous pirates: 
[t] he history of this country has very little to aid the writer of fiction, whether the scene be laid on the land or on the water. With the exception of the well-known, though meager incidents connected with the career of Kidd, indeed, it would be very difficult to turn to a single nautical occurrence on this part of the continent, in the hope of conferring on a work of the imagination any portion of that peculiar charm which is derived from facts clouded a little by time. ([1828] 1991, 429)

In this context, the pirate can be read, like the 'Indian,' as a result of a '(post-)colonial complex' in which American culture was perceived as inferior and poor in topics of its own in comparison to Europe; hence the craze for Native 'Indian' figures and scenarios in early and antebellum America, or for (Americanized) pirates such as the Red Rover. Across the Atlantic, readers of the nineteenth century were infatuated with such tales of piracy, which, as a subject, had already become "entwined with the history and legend of the new nation" (Walker 1963, xv)—after all, its first naval war was fought against "Barbary Pirates" (1801-1805, see Sect. 3.1), and figures like Captain Kidd (who is already mentioned in The Pilot) and Jean Lafitte fed a fledgling U.S. folklore. ${ }^{13}$ But even with Kidd as an inspiration for The Red Rover (as well as for The Water-Witch and The Sea Lions; see Bonner 1946, 21), Cooper admits the necessity of an "invention of tradition" (Hobsbawm and Ranger 1992) in the following, saying that the narrative has no factual basis; he was trying to "giv[e] the country, in fiction, that which he felt it lacked in history" (Clohessy 2007 , n.p.). This actually responded to the Rover's success as invented tradition, as many of its early readers actually believed the story to be historical fact (Blum 2008, 91). According to Bonner, The Red Rover is singular because by the very invention of the protagonist Cooper "saw the meaning in American Colonial life of Captain Kidd and all alike him," catching "the early spirit of independence that disregarded English law, that in the Revolution was patriotic and good, but that before that time had been criminal" (1946, 27). Cooper's adventure romances, in both form and content, then, dramatized a critical moment in the endeavor to develop a distinctly U.S.-American literature that had to situate itself in the Atlantic literary arena: formally by inventing what I call a realist romance, and in terms of content, by turning to the American Revolution, the maritime frontier-and piracy. 


\subsubsection{Legal Ambivalence and Independence}

The most influential and popular of Cooper's nautical romances in the nineteenth century, The Red Rover inspired important cultural protagonists on both sides of the Atlantic, like Goethe and Berlioz (who renamed one of his overtures Le corsaire rouge as a memorial to Cooper), Melville (who reviewed it while writing Moby-Dick) and Conrad (Walker 1963, xiv; Manning 1993, 450; Mackenthun 2004, 72), but was also widely popular in a plethora of simplified stage versions (e.g., Rennie 2013, 150); it gave its name to stage coaches, packet ships, and even a children's game (Th. and M. Philbrick 1991, xxix), and inspired mutineers-despite a somewhat confusing and obscure plot and a variety of aesthetic deficiencies. The story is set in 1759, during the phase of British conquest during the French and English Wars (1754-1763) in Newport, Rhode Island, which is depicted as a meeting place of various cultures: Puritan settlers, slavetraders, and Southern plantation owners on vacation, and the maritime multi-culture of the ships and the harbor; the important role of colonial Newport in both the slave trade and the history of piracy informed this image (Th. and M. Philbrick 1991, xviii). The action commences on a day of victory for the British troops against the French in the battle for Quebec, with a "spirit of Provincial admiration" (Cooper [1828] 1991, 438 ) for Britain pervading Newport. It revolves around the young seaman Harry Wilder, who, with his long-time seafaring companions Dick Fid and the African American Scipio Africanus (briefly called S'ip or Guinea), is on a mission to hunt down the famous pirate the Red Rover. He learns that a planter's daughter, Gertrude Grayson, and her governess Mrs. Wyllys, together with their African American (presumably enslaved) maid Cassandra, are to embark on the Royal Caroline on their journey back home to the Carolinas after a visit with her aunt, Mrs. De Lacey, sister of Colonel Grayson and widow of a deceased Admiral. ${ }^{14}$ A mysterious ship, the Dolphin, lying a little off the harbor, is suspected to be the Rover's rather than an "ordinary" slaver, a rumor left undisputed by an equally mysterious lawyer (a "stranger in green" who later turns out to be the famous pirate himself), and so Wilder and his companions take a nightly expedition to inspect the Dolphin. They are met by the former "lawyer," the Red Rover (a.k.a. Captain Walter Heidegger), who shows them various letters of marque and the flags of many nations and reveals his identity as a pirate who uses the flags at his own will. $\mathrm{He}$ 
offers Wilder to enlist as first mate, but Wilder objects, being afraid that he would not be free as part of the Rover's crew. While Dick and S'ip get drunk, Wilder is sent to study the ship's "code" (512) and eventually agrees to the position (apparently believing he can defeat the Rover more easily this way).

Wilder is now a double agent (though the reader learns much later of the fact that he is engaged in a royal pirate chase), and out of worry about the women tries to warn them of the Royal Caroline, a suspected future victim of the Rover. They debate his warnings, but decide to take the journey nevertheless. The Rover hears that the Royal Caroline's Captain is disabled with a broken leg and orders Wilder, with his companions, to apply for his post, presumably to make the capture easier. Presenting a fictitious letter of recommendation, Wilder is hired. They set sail, pass the mysterious Dolphin and are hailed by her captain; after a chase they turn back to Newport, but are caught in a tempest that leads to their wreck. While the mutinous crew leaves in boats, their pursuer, the Rover, saves the women and Wilder, and they continue aboard the Dolphin. During a theatrical masquerade (called "Mischief") that is to turn into a violent fight, the Rover restores order aboard, reaffirming Wilder's authority in front of the crew. Soon the women detect that they are now with the famous pirate and demand their release.

But the Rover sails on toward the Caribbean, where he encounters the Dart, a Royal Cruiser he tries to evade. Against orders, Dick Fid reveals the position of the Dolphin; Heidegger reacts by disguising himself as a pirate chaser, assumes the name of Captain Howard, and visits Captain Bignall of the Dart, where he realizes that Wilder is in fact Henry Ark, in pursuit of the Red Rover and enlisted with the Dart. Back on board the Dolphin, Wilder/Ark and his companions are imprisoned as traitors. The pirate code would demand that they be turned over to the crew for punishment, but upon a plea by Mrs. Wyllys, who turns out to be Paul de Lacey's (Admiral and Mrs. de Lacey's deceased son's) widow-is set free. Together with the women, Dick and S'ip, they are released to the Dart. Wilder returns to the Dolphin to offer the Rover amnesty as a reward for saving his and the women's lives on the condition that he destroy the Dolphin and refrain from piracy. Heidegger rejects the offer and Bignall prepares for battle with the (less well-armed) Dolphin, but dies, along with S'ip, defeated by the Red Rover. By chance it now turns out that Wilder/Ark is Paul de Lacey's and Mrs. Wyllys' son, and her mother's plea saves his life when the Dolphin's crew demands his death for treachery. 
In the morning, Heidegger-mission accomplished-disbands his crew, hands over the Dart to Wilder, and releases the women to go with him. As the Dart takes off, the Dolphin goes up in flames in a mysterious explosion.

In the last chapter, set twenty years later in 1779 , a sick old American naval officer lands in Newport harbor and is carried to the de Lacey's home, where Henry lives married to Gertrude and is father of a teenage son. The dying man turns out to be the Red Rover, carried by his former cabin boy Roderick, who now turns out to be his (cross-dressed) mistress (and thus can be read as the subjugated ancestress to Fanny Campbell; see Sect. 2.2). He is then recognized by Mrs. Wyllys (i.e., Mrs. de Lacey) as her long-lost brother and thus Henry's uncle. The Rover dies, unfurling an American flag from beneath his pillow and "laughing hysterically" as he shouts to Henry that "we have triumphed!" (868).

In the novel, Cooper's characterization of the pirate is ambivalent, divided between admiration for his independent spirit and condemnation of his lawlessness, and critics have struggled much with the function and plausibility of Heidegger's final vindication. On the one hand, the text follows Cooper's romanticized notion of piracy and privateering that he expressed in Notions of the Americans:

The privateers of this hemisphere were always conspicuous in the colonial contests; and they were then, as they have always been since, of a character for order and chivalry that ought not to be too confidently expected from a class of adventurers who professedly take up arms for an object so little justifiable, and perhaps so ignoble, as gain. $(1828,62)$

Notably, Cooper eliminates the profit motive from piracy in order not to make the Rover seem base and ignoble and to legitimize him as an avant-garde American gentleman "pirate" by suspending issues of class, superimposing, instead, a maritime chain of command and order. On another level, the text's emphasis on moral law in a nationalist context likewise belittles economic aspects of gain in the American Revolution visà-vis moral and meritocratic ones. Rather, the narrator of The Red Rover emphasizes (here through the eyes of Mrs. Wyllys) the pirate's "chivalrous generosity" ([1828] 1991, 750) and even grants him a sense of justice: "he bore the character of one, who, while he declared himself the enemy of all, knew how to distinguish between the weak and the strong, and who often found as much gratification in repairing the wrongs of the former, 
as in humbling the pride of the latter" (my emphasis). While the quotation evokes the legal concept of the pirate as hostis humani generis, "the enemy of all," it unmasks it as legal fiction, as the Rover appropriates it in his self-description as a mere performative declaration (perhaps to instill fear in his opponents) and instead makes clear distinctions between "weak" and "strong," friend and foe.

In a scenario of power asymmetries like that of colonial dependence, the Rover seems heroic for his independence and autonomy. Disguised as Captain Howard, Heidegger expressly distinguishes the Rover (who, like Howard, turns out to be only one of his temporary identities) from "an ordinary freebooter-one coarse, rapacious, ignorant, and inexorable" (806-807) in his conversation with Bignall; indeed, he emphasizes that his crew is governed by ancient pirate laws and, even more significantly in the context of the history of the American colonies, a "covenant"; dissolving his crew, he states that "we have long been submissive to the same laws. ... You cannot charge me with injustice. But the covenant is now ended. ... The compact ceases, and our laws are ended" (859). Harking back to the language of the Declaration of Independence and the Nullification Crisis topical at the time Cooper was writing, the Rover's nullification invokes the founding legal documents of the United States, insinuating that his behavior is to be seen as a similar legal and legitimate act; as individual freedom "is an indispensable condition of true law, ... the Rover's personal act of nullification provides ... the sine qua non of constitutional government. Even a democracy of thieves is, Cooper asserts, preferable to a criminal despotism" (Adams 1990, 96).

In the Rover, pirate law is mutually agreed upon and temporary rather than authoritarian and infinite; instead of appearing as an entirely lawless figure, the pirate suggests that there are other ideas of law competing with "legal law" - at the time of the novel's action, British law. Thus the tale functions as an arena in which law, as a social and political institution, is tested in its various versions; "[a]s a metaphor through which to evaluate character, the law provided Cooper both a fixity of absolute standards, and an opportunity for debate among alternative ideas of just behavior" (McWilliams 2004, 15-16; also Schneck 2007). In this context, the Rover personifies the same law of nature, powerfully evoked through the language of the oceanic sublime (used predominantly in the tempest scenes), to which the founding fathers appealed in the Declaration of Independence (Mackenthun 2004, 77). As he is portrayed as a (temporary) figure of identification and admiration for both his foil Wilder and 
the reader, Heidegger's anti-legal, vindictive position on piracy, authority, and legitimacy, as well as his deceptions and disguises, provoke a normative crisis of legal ground and moral order in the text, which is also staged as a crisis of comprehension and perception (foreshadowing Melville's "Benito Cereno"). As Michael Rogin observes, the Rover

takes on identities at will; no lawyer or captain is safe from suspicion once the Rover has imitated their characters. As the Rover appropriates and discards legitimate roles, he dissolves them ... . This split between authority's appearance and its genuine character undermines the constituted order. Disguise destroys one's confidence in a stable, morally legitimate world. ([1979] 1985, 5)

The contrivances and improbabilities of the plot formally echo this crisis of comprehension and narration and indicate the text's indecision and ambivalence, thus constituting more than just literary flaws; in this way, the book is also concerned with interpretation and the contrast between superstition and appearance on the one hand and knowledge on the other (Adams 1988, 157). Of course, the oceanic setting is perfect for evoking mists and hazes, tempests and blurred vision (Adams 1990, 84). Similarly, rumor, superstition, and disguise are core themes throughout the tale, as actual appearance/performance and expected identity are set against each other. Bignall remarks upon Henry Ark's revelation that the "Captain Howard" who visited his ship is actually the Rover: "This is unaccountable! extraordinary to a miracle! His disguise was very complete ... . I saw nothing, Sir, of his shaggy whiskers, heard nothing of his brutal voice, nor perceived any of those monstrous deformities which are universally acknowledged to distinguish the man'" (Cooper [1828] 1991, 822), to which Ark replies: "All of which are no more than the embellishments of vulgar rumor. I fear, Sir, that the boldest and most dangerous of all our vices, are often found under the most pleasing exteriors ... . His body is not large, but it contains the spirit of a giant." Time and again, the Rover sarcastically refutes the notion that pirates are monsters in the devil's service: when Wilder first visits the Dolphin, he asks: “Am I what report has made me? Look keenly at the monster, that nothing may escape you,' returned the Rover with a hollow laugh, in which scorn struggled to keep down the feelings of wounded pride. 'Where are the horns, and the cloven foot! Snuff the air: is it not tainted with sulphur?"” (511). ${ }^{15}$ 
Piracy, for the Rover, is neither monstrous nor devilish, but is instead the performance of American-ness avant la lettre, as he expresses in another conversation with Wilder: "I am not fitted for the world, as it is found among your dependant Colonists",; "You have seen my flags, $\mathrm{Mr}$ Wilder, but there was one wanting among them all. Ay, and one, which had it existed, it would have been by pride, my glory to have upheld with my heart's best blood!" ( 725 , clearly referring to the starspangled banner). He argues for his legitimacy because he cannot appeal to legality; avant la lettre hence also means "before the letters of law," before the existence of an independent American body of law in this context. Heidegger's turn to piracy is made explicit by his experience of inequality and oppression as an American in the same conversation:

Were [the advantages of your country] known as they should be, by you and others like you, the flag I mentioned would soon be found in every sea, nor would the natives of our country have to succumb to the hirelings of a foreign Prince. ... Had that flag been abroad, Mr Wilder, no man would have ever heard the name of the Red Rover. ... I could be a subject of a King, but to be the subject of his subjects, Wilder, exceeds the bounds of my poor patience. I was educated, I might have almost said born in one of his vessels, and how often have I been made to feel, in bitterness, that an ocean separated my birth-place from the footstool of his throne! (725-26)

The reader learns that Heidegger became the Rover because he killed "“a native of the holy Isle" who slandered America: " "the King rendered a faithful subject desperate, and he has had reason to repent it" (726). Heidegger's piracy is “a substitute for revolutionary action" (Peck 1976, 597), because if America had been independent, he would never have become a pirate and fought his "private war of independence" (Philbrick $1961,56)$; hence the practice of piracy is directly linked to the cause of independence (Clohessy 2007). According to Dekker, "the outlaw Rover" is in fact "the only character in sight who perceives that American commercial and civic well-being can be obtained only through independence" $(1967,116)$. The text insinuates a pervasive, justificatory rationale for Heidegger's piracy by representing the Rover as a proto-revolutionary in the struggle against British colonial oppression (which was certainly appealing to an early nineteenth-century American readership in need of a "usable past"). 
The use of the color red in the novel's title and the pirate's name is also significant in this context; Cooper, knowledgeable about the French Revolution and witnessing the oncoming of the labor movement in France that would lead to the July 1830 Revolution, used a color that signified liberty and personal freedom and had been employed by radical parties like the Jacobins, many of whom wore red Phrygian caps (also called liberty caps) modeled after those worn by freed slaves in ancient Rome. ${ }^{16}$ The color of freedom (on the one hand), red also symbolized the blood of those who struggled for liberty and those killed by tyranny; it had also been prominently used in seventeenth- and eighteenth-century pirate flags such as Edward "Blackbeard" Teach's, Edward Low's, John Phillips', or Christopher Moody's. Heidegger expresses his (premature) revolutionary sentiments repeatedly, thematizing the oppression of white creoles who are treated "as ... of an inferior order" (Cooper [1828] 1991, 783 ) in a tyrannical colonial system: "Was your merit called Provincial; did they read America in all you did?" the Rover asks Wilder about his experiences aboard the "Royal cruiser." Even if the import of the Rover's revolutionary sentiments is never formulated, the text renders it clear that Heidegger's Byronic nobility is host to a prophetic sense of America's future national freedom (Manning 1993, 450). He is "the outlawed visionary who alone perceives the drift of history" (Philbrick 1961, 56), a "drift" that is seen, as the quote also shows, in the Rover's vision of the flag to "be found in every sea," as America's course toward empire, "thereby spelling out the fatal causality from which the U.S. derives its national identity" (Mackenthun 2004, 80).

It is the United States' legal identity as a postcolonial nation that is at stake in The Red Rover, in which a search for a stable code of political justice is set against core revolutionary values of liberty and political change, civil law against natural law (McWilliams 2004, 26). Cooper counterbalances a de facto anti-legal, libertarian portrayal of the Rover by characterizing him at the same time as an authoritarian ruler whose verdicts are rather arbitrary, whose rules are rigid and whose will is quite imperial, for example in the "Mischief" episode (see Adams 1988, 160) or when Wilder is to be hanged for treason and the Rover explains that this is what the "law which binds together this community" (Cooper [1828] 1991, 808) demands-only then to make an exception. Introduced as a barrister, an executor of existing law, the Rover is unmasked subsequently as a self-styled creator of law instead. Order and chivalry are countered by a dark romanticism reminiscent of Byron's Corsair, "the noble outcast, 
the aloof and inscrutable superman, the passionate, guilt-ridden sufferer"; a "victim[] of thwarted ambition" (61-62), restless and serious in character. But, as Adams points out, Cooper (unlike Byron) eventually rejects anarchic rebellion, turning the lawless, extra-juridical, "neutral ground"17 or apeiron (Lewis 1955, 99) of the ocean into a world of law (Adams 1990,83 ) in the course of the narrative; eventually, the Rover is a "dark parody of the Byronic hero" (86), a "man who claims a legal authority for his actions, but is in fact ruled by his lawless impulses" (89) and therefore is eventually tamed by the narrative. ${ }^{18}$

The choice of a pirate as a pre-revolutionary freedom fighter and the text's ambivalence toward the Rover also expresses doubt about revolution as a politically legitimate act, especially concerning its violent and socially rebellious aspects. Revolution, in Cooper's work, can be a form of "moral piracy" (Peck 1976, 595), even if The Red Rover is perhaps his "most unqualified celebration of the revolutionary spirit." 19 As the text neither entirely rejects nor completely endorses the Rover as a U.S.American hero but rather constructs him as a personification of the nation's constitutive legal crisis, it instead introduces Wilder, his foil and double, as a foundational figure for a future United States. The Rover and Wilder's lengthy conversations are crucial moments in which they question each other's legitimacy and authority, and because of the Rover's patriotic discourse, Wilder temporarily loses his sense of duty (and self) as a pirate chaser-and becomes an outlaw himself when he sends away the pilot of the Royal Caroline lacking any legal basis (and by this act almost incites mutiny). Henry Ark, one of Cooper's "middle heroes" (Peck 1976, 597), indeed becomes "W/wilder" in the course of the narrative, but eventually overcomes this crisis of identity by turning into an ambitious, meritorious, and professional young man, moving up on the social ladder - thus the transformation into Ark, echoing Noah's Ark, a solid, life-saving vessel (in contrast to the Dolphin, which is always in some sort of disguise and in the end is destroyed). Once he has formed such an "Ark," the last step is his elevation in terms of social class by becoming (yet having always been) a de Lacey. From this perspective, the novel is also Wilder's story of initiation; his "faith in law has matured from mindless obedience to rules, into a commitment founded on a deep knowledge that its alternative is unacceptable" (Adams 1990, 96; also Th. and M. Philbrick 1991, xxxv). Virtue and talent triumph in this Jeffersonian vision of a "natural aristocracy of merit" (McWilliams 2004, 47), and 
it is Wilder rather than the Red Rover who personifies the "heroic UrAmerican" McWilliams describes (65); in the words of Charles Hansford Adams: "when we consider his mastery of the Rover in light of his eventual identity as a hero of the American cause, we see that his part in the moral drama of Red Rover is to lay the foundation for the Revolution by quelling anarchic impulses that might threaten its integrity" (1990, 92). Wilder, unlike the Rover, also succeeds in integrating law, perception, and identity into a comprehensible structure (Adams 1988, 159).

\subsubsection{Crises of Authority and the Absent Presence of Slavery}

The multiple crises of authority among all kinds of characters are significant in the context of envisioning a U.S.-American future on the basis of natural law: besides the Rover's and Wilder's authority, such competition takes place also between the women and the men, as well as among the women themselves (e.g., Mrs. de Lacey and Mrs. Wyllys debating their seafaring experiences) and the various crews. Adams interprets the articulation of such conflicts as the text's "effort to reconcile the claims of self with the prerogatives of the various structures of authority that condition individual freedom" $(1990,82)$, but these crises also echo and negotiate more general questions of legitimacy topical at the time Cooper was writing, triggered by anxieties about the state of the Union and potential forces of disruption through external and internal pressures (Manning $1993,451)$.

The greatest of these anxieties certainly related to slavery in the new states and was itself framed by interpretative conflicts between natural and civil law. Readings from a Black Atlantic perspective have recently drawn attention to Cooper's literary response to slavery and the slave trade, which often constitute "absent presences" (Mackenthun qua Toni Morrison 2000, 537) in his texts. The themes of piracy and slavery also interrelate in another way considering the historical contexts of both 1759 and the 1820s: Mackenthun reads The Red Rover as enacting the postcolonial conflict between the United States and Britain regarding the legal battles over the abolition of the slave trade, which America halted in 1824 by refusing Britain's claim to a right of search of any American vessel for illegal slaving $(2004,79)$. The motif of disguise and the debates over the Dolphin's status as either pirate or slaver, which takes up almost a quarter of the novel, is significant in her view: 
A fictional exploration of the common confusion about the legal distinction between slavers and pirates and about the jurisdiction to be applied, The Red Rover is an emplotment of Britain's desire for boarding suspected American ships. ... In projecting back the contemporary conflict over the illegal slave trade to the period of America's revolutionary battle against Britain, the novel also casts the present violations of international law by reckless American entrepreneurs as morally legitimate. The present debate over the limits of America's national jurisdiction in outing an end to an internationally prohibited commerce is imaginatively enacted as a revolutionary struggle for America's natural right of national independence. $(79)^{20}$

Mackenthun suggests that the confusion of pirates and slavers-mostly due to the Dolphin's disguise as a slaver in the Newport harbor-and the book's emphasis of disguise and deception, especially by the arbitrary use of flags, indicate doubt about the role of the United States in the transatlantic slave trade. Other Black Atlantic readings focus on Cooper's (under-)representation of African Americans, which Boggs calls an act of "blanching" the Atlantic (2007, ch. 2); similarly, Appiah argues that in Cooper's racial scheme, in which the Native American is below the white man but above the black, blacks usually evoke disdain (similar to the Jew in Scott's Ivanhoe) and merely provide "point[s] of contrast that allow[] us to understand the sympathies between the members of the first two races" (white and Native American in Cooper, Anglo-Saxon and Norman in Scott, 1995, 281-82), while Wallace, in his examination of "The Black Sailor and The Red Rover," places Scipio at the center of the text, which he reads more positively as allowing "for at least some movement between [racial] categories" $(1999$, n.p.). Both the process of "blanching" and the disruption of racial characterization become evident in an understudied episode in which Scipio provokes a crisis of knowledge and authority by using a style of communication reminiscent of "signifyin" or "double talk" (Henry Louis Gates), again prefiguring "Benito Cereno." The Rover asks Scipio, who on the surface acts like a devoted slave and is represented by the usual racial stereotypes of the early nineteenth century, for his opinion regarding the distance of a ship that turns out to be the Dart. Scipio, who "had been chosen for his expertness to perform the task in question" (Cooper [1828] 1991, 765) is disproportionally submissive at first, "[p]lacing his cap on the deck, in a reverence far deeper even than that which the seaman usually manifests toward his superior"; his assessment is praised by the Rover: "The tongue of your 
negro, Mr Wilder, is as exact as a carpenter's rule. The fellow speaks of the size of a vessel that is hull-down, with an air as authoritative as a runner of the King's customs could pronounce on the same ..."' (766). The Rover has interpellated Scipio into a subject position transgressing boundaries of race, which denied an African American any voice of authority, but Wilder dismisses S'ip's opinion: "You will have consideration for the ignorance of the black; men of his unfortunate state are seldom skilful in answering interrogatories.'" The Rover is not convinced by Wilder, and Scipio's reaction is to roll his

large dark eyes ... from his new commander to his ancient master, while, for a moment, his faculties appeared to be lost in confusion. But the uncertainty continued only for a moment. He no sooner read the frown that was gathering darkly over the brow of the latter, than the air of confidence with which he had pronounced his former opinion vanished in a look of obstinacy .... . (766)

Asked again by the Rover to confirm his opinion, Scipio realizes that he has triggered a struggle of authority between the Rover and Wilder in which he cannot win; his loyalties are divided between his racist "ancient master" and the outlaw-revolutionary Rover (who seems not to differentiate according to ethnic categories among his crew, which includes many European nationalities as well as Native Americans). Thus Scipio's subsequent answers resume, on the surface, a submissive slave's position ("He'm just as Masser wish 'em," 767). This incites the narrator to describe him as an "obstinate black," refusing reasonable communication. Fid intervenes, but even S'ip's long-term companion cannot quell his spirit of resistance:

He turned his eyes, in great disgust on Scipio, to vindicate the credit of the association at the expense of some little contempt for the ignorance of his companion. "What the devil do you take [the ship] for, Guinea; a church?" "I t'ink he'm church, too," responded the acquiescent black. "Lord help the dark-skinn'd fool! Your honor knows that conscience is $\mathrm{d}$-nably overlooked in Africa, and will not judge the nigger hardly for any little blunder he may make on account of religion. But the fellow is a thorough seaman, and should know a top-gallant sail from a weathercock. Now look you, S'ip, for the credit of your friends, if you have no great pride on your own behalf just tell his-" (768) 
Scipio's sense of pride will not be quenched, and the Rover realizes this, stopping the discussion at this point. The fact that S'ip's calculations turn out to be correct, however, highlights his expertise and potential authority; the episode can perhaps be read as a subtle critique of Wilder's (and thus of a foundational U.S.) racism. Still, S'ip has to die eventually (defending Wilder in the battle against the Dart); in the death scene, Fid finally recognizes the injustice of race, begging "a pardon of a black man" (853) as "it may be that I have rode you down a little too close myself, boy, when overheated with the conceit of skin'" and pleads the others to let S'ip speak: "When there is so little time given to a poor fellow to speak his mind in, it may be well to let him have a chance to do most of the talking. Something may come uppermost, which he would like to send to his friends in Africa" (852).

While black characters certainly profit from the quality of the oceanic setting in sea fiction, in the sense that their merits allow for "recognition that a lifetime of patient toil on land would not obtain for them" (House [1965] 1979, 143), skill and merit do not save S'ip from dying for his master. Revolutionary in many other respects, the tale hence propagates a mild form of resistance to slavery at best-both through the pirate (e.g., when he offers Scipio gold as payment for his services that S'ip refuses to take, 713) and Gertrude, who calls the slave trade "vile" (590).

Gardner convincingly argues that there is a correlation between Cooper's treatment of blacks and Native Americans in the context of the Missouri Crisis, arguing that his work tries to "erase race from national identity" by a logic "in which the myth of the Vanishing American brings about the vanishing of slavery, the state of Missouri, and the very fact of racial difference altogether" (quoted in Boggs 2007, 76). As "shadows of presences from which the text has fled" (Mackenthun 2000, 536), both Scipio and Cassandra are representative of the debated and precarious position of African Americans-enslaved and free-in Cooper's sea tales. Read against the grain and in the context of the Black Atlantic, The Red Rover is significant in the sense that its attempt to silence the crisis over race cannot be entirely successful. Africa, slavery, and the slave trade are present throughout the text, despite its relegation of these topics to the margin; the characters of Scipio (born in Africa and at one point called "Mr. Gold-coast," Cooper [1828] 1991, 453) and the enslaved Cassandra, even though highly conventional and full of stereotypes, are constant reminders of the presence of African Americans and the (continuing) experience of the Middle Passage that disturb, in the 1820s, the 
legal identity of the United States as a civil society based on natural law. In addition, their discursive domestication-by means of both plot and the use of stereotypes - can also be read as the symbolic quenching of slave uprisings, which, at least since the Haitian Revolution (1791-1804), were perceived as a constant threat to the socio-political order throughout the American Atlantic; it is in this context that the Caribbean as the setting of the final confrontation between the Rover and his chasers is significant.

Cassandra's character, which is largely glanced over in previous readings of The Red Rover, is also inscribed with a sense of resistance and a plot-altering agency, though weaker than Scipio's. She is responsible for the rescue of her shipwrecked mistress and her associates by the Rover, waving a white flag as soon as she detects the ship. This act is described as rebelliously triumphant on the one hand, but devotionalsolely concerned with her mistress's survival - on the other; a devotion engraved more deeply in Cassandra than Scipio. She has internalized the absent authority of her owner, General Grayson:

Cassandra alone was rebellious. She made stout objections, against even a moment's delay, assuring the inattentive young seaman [i.e., Wilder], that should any evil come to her young Mistress by his obstinacy, General Grayson would be angered, and she left him to reflect on the results of a displeasure that to her simple mind teemed, with more danger than would attend the frown of a monarch. Provoked by his contumacious disregard of her remonstrances, the negress, forgetting her respect, in boldness on behalf of her, whom she not only loved but had been taught to reverence, seized the boat hook. ... Then indeed, she lowered the signal, before the dark look of Wilder. Short as was the triumph of the negress it was crowned with success. (680, my emphases)

Cassandra's disobedience, which leads to their rescue, is not against her lawful mistress or owner (hence Cassandra survives unlike Scipio), but against the only man aboard, Wilder, who is afraid the ship might be inimical. Gertrude, in contrast, has "no fears of a generous enemy," convinced that "[e]ven a pirate would give shelter and welcome to females in our distress" (679) - an opinion based on a romantic notion of piracy that proves correct only because the Rover is a gentleman pirate. The crisis over authority in a scene of shipwreck thus concerns not only a crisis in racial categorization-after all, an enslaved African American woman's "simple mind" leads to the group's rescue-but also gender relations, in this and many other scenes in which female characters question male 
authority (especially if they have sea experience of their own like Wyllys). Women, their experiences and their emotions hence represent another danger like that posed by racial difference to Cooper's vision of order and social cohesion, which can be seen as the reason why his tales often replace the heterosexual romance with a sentimentalized version of friendship between men (Fluck 1997, 117). The uneasy presence of outspoken women at sea, in The Red Rover, disturbs the novel's conception of American masculinity whose authority is based on competence, merit, and competition rather than privileges of birth (which is typical of the discourse of adventure, 113-16).

The cracks of The Red Rover's meritocratic vision, its de-hierarchizing appeal, can be found in the presence, however obscured, of those who are denied participation; from this point of view, the Rover's unlawful resistance against oppression would have to be continued far beyond American independence. The Red Rover's ending is conservative, containing the book's revolutionary potential and reaffirming rank and hierarchy; as Mackenthun observes, it "plots, and 'romances,' the national emergence of the United States as a reunification of a family" by staging "a dynastic (not to say incestuous) marriage between a New Englander and the daughter of a Southern plantation owner ... coupled with the domestication of the pirate" $(2004,73)$; it "defuses the threat inherent in the Rover's political shapeshifting and suggests that pirates like the Rover, who prefer an existence in lawlessness to the toleration of unjust colonial bondage, vanish together with the end of the colonial period" (75). But as Michael Rogin ([1979] 1985) points out, The Red Rover's subversive potential seems to have surpassed its conservative agenda in the minds of many nineteenth-century readers, such as mutineer Philip Spencer, son of the Secretary of War, who was executed in the famous U.S.S. Somers mutiny of 1842; Spencer had claimed that Cooper's Rover inspired his "career" (Mackenthun 2004, 72). Notably, Cooper was one of the few of the American elite to defend Spencer (while Melville's cousin was second in command on this very ship). This development was criticized by contemporaneous American commentators, who complained that outlaws were becoming American heroes, as in the journal Port Folio:

An individual who is represented as the terror of the seas-as the reckless violator of law and right, should not be invested with the finest qualities of the man and of the gentleman. We think them not only incompatible, but tending to sanction murder and robbery. Lord Byron and the 
German writers have sufficiently disgusted us with that description of heroes. (quoted in Dekker and Williams 1997, 12) 21 $^{2}$

The complaint is misdirected, however, since Cooper's text explores both the positive and negative potentiality of the pirate: The Red Rover leaves us with a question rather than a statement, asking whether and under what circumstances piracy can be a form of outlaw patriotism, but also how the crisis of authority and legitimacy, articulated through the pirate, can be overcome. In this way, Peter Schneck's conclusion in his discussion of legal evidence in Cooper's Pioneers also holds true for The Red Rover: that the text, in a paradoxical way, "both critiques and legitimises law and legal authority" and that "it may be read both as a critique of political justice, and a celebration of legal institutions and the authority of law" (2007, 58). Piracy in the Rover functions as a trope through which to discuss right and wrong, legality and legitimacy, and to debate ways in which U.S.-American law could emulate natural law-not only in the post-revolutionary context of independence, but also (even if in spite of itself) with regard to slavery. The tale's solution restores an intact social and legal order, with all unruly characters domesticated. By relegating the question of slavery and natural law to the margins, it fails to integrate blacks and women as subjects into that order (Anderson 1951, 23) - a failure that would keep the nation in a critical state for much of the rest of the nineteenth century.

\subsection{Cross-Dressing and Piracy In Lt. MURRAY's FANNY CAMPBELL (I844)}

\subsection{1 "Values and Virtues in Crisis"}

I have argued in the preceding chapter that the pirate's identity is drawn as unstable and performative rather than either clearly heroic or evil in The Red Rover, echoing the novel's ambivalent positioning regarding the legitimacy of piracy; as Thomas and Marianne Philbrick have put it: "In the Rover himself and his premature declaration of independence, we trace the fine line that separates the pirate from the patriot, a distinction that sometimes seems less a matter of motive than of timing" (1991, xxxv). Despite its ambivalences, The Red Rover's popularity established the romantic pirate of Revolutionary times as a heroic outlaw figure, productive of a collective national identity for the young Republic. Being 
perhaps the earliest and certainly the most popular instance of a plethora of nineteenth-century narratives that romance piracy, Cooper established a pattern that projected piracy back to the age of the American Revolution and retold historical events in ways that naturalized the development of the United States as that of a 'piratical,' illegitimate nation-in-themaking into an expanding nation of grandeur and legitimate political significance. These stories reaffirm the act of emancipation as a response to the crisis of political legitimacy of colonial rule in the 1770 s while simultaneously negotiating contemporaneous scenarios of crisis in terms of race, ethnicity, and gender relations, but also of class and citizenship. In his study of popular cultural memory of the American Revolution in the mid-nineteenth century, Karsten Fitz describes the decades from the 1830 s to the 1850 s as "the extreme case of the nation and its values and virtues in crisis" $(2010,262)$ :

The 1830s to 1850s represent a unique period in American cultural history, a period which put the American founding principles-life, liberty, the pursuit of happiness, and individual property-to an extreme test that threatened to destroy a nation that was culturally, geographically, and politically still in the making. While a collective cultural identity was being constructed, it was also a period of radical ruptures in U.S. society in which cultural memory is extensively created with multiple agendas ... $[\mathrm{N}] \mathrm{o}$ doubt, the increasingly conflicting political and cultural developments in the antebellum U.S. - continuing slavery in the South, culminating sectional strife, newly emerging antagonisms with regard to women's suffrage, as well as increasing immigration and urban conflict—represented just such elements of national crisis. $(11 ; 262)$

Images-and narratives, one could add-about the Revolution in the antebellum United States functioned to "impose coherence and meaning on an American collective national experience," mirroring the conflicts of their time (63). ${ }^{22}$ Fitz identifies the "David vs. Goliath-motif" (77) as the central narrative in this context, which emphasized the defeat of a much more powerful Britain as due to the patriotic spirit and perseverance of the American population. Lieutenant Murray's (i.e., Maturin Murray Ballou's) popular novelette Fanny Campbell (1844) ${ }^{23}$ takes up this motif, romancing the Revolutionary crisis while at the same time negotiating the prevalent conflicts of the antebellum period through the figure of a cross-dressing female pirate fighting at the onset of the Revolutionary War. 


\subsubsection{Popular Novelettes and Piratical Adventure}

In the 1830s and 1840s, the romantic pirate enters mass-market literature and is popularized among newly emergent readerships: a rising middle class of men and women as well as immigrants. Maturin Murray Ballou (1820-1895) of Boston, the son of a Harvard University preacher and author and publisher of popular literature, is best known as the editor of the widely successful illustrated magazine Gleason's Pictorial Drawing Room Companion, which he cofounded with Frederick Gleason in 1851 and took over in 1854 (hence its renaming as Ballou's Pictorial Drawing Room Companion) and first editor of the Boston Daily Globe. Following the model of the London Pictorial News, Gleason's/Ballou's Companion, like many other publications of the day, demonstrate the extent to which American publishing was still transatlantically oriented, emulating the fashions and trends prevailing in Great Britain. Yet Ballou's intent was to found a distinctly American medium, printing only American authors (Belasco 2007, 264). His own writing (under his pen name Lieutenant/Lt. Murray), which he published since the mid-1840s with his coeditor Frederick Gleason's press or in the series The Weekly Novelette, usually consisted of travel narratives or adventure tales, which often took place in the American past. Besides Fanny Campbell, first published with the subtitle The Female Pirate Captain. A Tale of the Revolution, he also wrote pirate narratives such as The Naval Officer; or, The Pirate's Cave! A Tale of the Last War, Red Rupert, the American Bucanier: A Tale of the Spanish Indies (both announced as sequels to Fanny; 1845), The Scarlet Flag; or, The Caribbean Rover: A Story of the Early Buccaneers (Novelette 90) or The Pirate Smugglers; or, The Last Cruise of the Viper (Novelette 137). Murray was Gleason's most successful author; Fanny Campbell, the first and most successful of these novelettes, sold more than 80,000 copies within a few weeks and ran into numerous, mostly illustrated editions available across the United States, including a few southern cities, well into the 1870s (Streeby 2002, 88; Anderson $2011,97) .{ }^{24}$ It seems that Fanny's success was responsible for Ballou and Gleason's founding of what would become the largest publishing plant in the United States.

Novelettes, as a genre of popular literature in the United States, were a new phenomenon of these decades, when technological developments in the printing trade made cheaper productions possible and new marketing techniques made them successful. ${ }^{25}$ The literacy rate had 
risen disproportionately compared to the income of the U.S.-American population, for many of whom bounded books were much too expensive-facts that, taken together, guaranteed great market prospects for cheap reading material (Neuburg 1983, 82). By the 1840s, innovations in printing technology, publishing, and book distribution had led to the marketing of inexpensive, mass-produced popular histories that subsequently exerted a profound influence on historical literacy and learning in the United States, as Gregory Pfitzer demonstrates in his study Popular History and the Literary Marketplace, 1840-1920 (2008). ${ }^{26}$ Publishers of popular works hoped to benefit from economies of scale by selling large numbers of inexpensive popular histories at small profit; they hired authors to write effectively for wide audiences in order to make the past accessible to readers who otherwise could not afford to buy books. Beginning as a small cottage industry, popular histories sold in the hundreds of thousands by the 1890s (Pfitzer 2008, 7). They negotiated the prevalent issues of the age by actively constructing a popular collective memory of formative historical events such as the Revolution on the one hand, and by their educative intent and didactic impulse sought to form a cohesive American subject on the other. Yet they needed to be entertaining as well; bridging Puritan morals and the taste for adventure, tales of popular history, including oral histories (folk tales, legends, and similar forms), were actively promoted by publishers like Gleason. Both Fanny Campbell's historical setting and the plot perfectly fulfilled Gleason's criteria for publication:

We wish for such contributions as shall be strictly moral in their tone, highly interesting in their plot, replete throughout with incident, well filled with exciting yet truthful description, and, in short, highly readable and entertaining. Domestic stories, so-called, are not exactly of the class that we desire; but tales - of the sea and land - of the stirring times of the revolution-or of dates still farther back-are more in accordance with our wishes. (quoted in Streeby 2002, 89)

Streeby asks how a publisher like Gleason, primarily interested in selling his mass products, could distance himself so explicitly from the highly popular sentimental literature (predominantly written by women) and asserts that this programmatic statement was by no means a total refusal of the sentimental mode as such; in reality, the sensational and the sentimental, adventure and romance, went hand in hand in Gleason's 
publications. This also holds true for Fanny Campbell, an adventure story that shares many qualities with sentimental literature, such as the focus on the romantic love-story and the discourse of emotion ${ }^{27}$; because of its female protagonist, it primarily spoke to female readers, who would otherwise not necessarily favor popular histories over sentimental love-stories. ${ }^{28}$ Thus I do not agree with David Reynolds's much too schematic typology of antebellum popular literature, which views Fanny as "Dark Adventure," featuring "only occasional philosophical commentary, usually dark" $(1988,183)$ and characters such as "pirates, corsairs, freebooters, swaggering ship's captains, mythic monsters, and so forth" (188)-as opposed to "Moral Adventure" (both instances of "Romantic Adventure fiction," 183), "Conventional" (i.e., "pious domestic fiction," 182), and "Subversive" fiction (which was "deliberately subversive in both the stylistic and the political sense," 183). Indeed, Fanny combines characteristics of all of these: moral commentary, even didacticism; a conventional domestic ending; and at least potentially subversive historico-political interpretation, if perhaps not a subversive style. Importantly, it also marks an instance of a print culture that "functioned as the foremost medium for circulating stories of filibustering expeditions and advocating for national expansionism" (Woertendyke 2013, 215).

\subsubsection{Fanny: A Tale of the Revolution?}

Fanny Campbell features the story of a young woman in the old, Puritan fishing hamlet of High Rock near Lynn, not too far from Boston, ${ }^{29}$ representing a counter-model to "true womanhood," as the narrator underscores the "adventure-feminist capabilities of his heroine" (Reynolds 1988, 347): a captain's tomboyish daughter and "noble looking girl" (Murray 1844, 12), she not only knows much about navigation: she "was none of your modern belles, delicate and ready to faint at the first sight of a reptile; no, Fanny could row a boat, shoot a panther, ride the wildest horse in the province, or do almost any brave and useful act," but could also "write poetry" and is "looked up to in all matters of information and scholarship" because of her "excellent education." Nineteenth-century norms of femininity are dismantled in critical comments on dress codes and beauty as dangerous for women's health; notably, the following description of one of the villagers, sixty-year-old widow Herbert, applauds older generations of women: 
The refinements of civilization had never marred her health or vigorous constitution, for she had never resorted to those means of shortening life practiced in these more advanced periods of refinement. No cramping and painful corsets had ever disfigured her fine natural form, nor had her feet ever been squeezed into a compass far too small for their size, in order to render them of delicate proportions. No, no, the good old practices of the Bay Province seventy and eighty years ago, were productive of hale and hearty old age .... . (24-25)

This, so the narrator, also has to do with the rough life in the village: "The dangers that often times surrounded the homes of the females, gave rise to a stern and manly disposition even in those of the gentler sex who formed a part of the community, and altogether it was made up of stern and dauntless spirits" (11). From the beginning, the text differentiates between "refined civilization"'s ideals of femininity, connoted as negative, and "natural" feminine forms, associated with the "healthy spirit" of the lower classes - to and for which it aims to speak — and with the eighteenth century; "the good old practices of Bay Province seventy and eighty years ago" (24).

The preface makes the reader expect a "very romantic" (7) tale, "but no more so than many others, the incidents of which occurred during the stirring times of the Revolution, and which have since received the sanction of history." From the beginning, the Revolution is cast in a romantic mold, distanced from the contemporaneous readers' present by describing it as a "sanctioned" chapter in American history that is retold in the novelette in order to solidify this national narrative among new audiences: "No American can, or rather should, be unacquainted with the principal events" (74) of the Revolution. Chapters frequently start with an overview of Revolutionary events like the battle of Lexington and Concord, Bunker Hill (both 39), or the Boston Blockade (ch. 8), but also include oral history accounts and tales about legendary figures of the Revolution like Moll Pitcher (ch. 1, 8, and 11) or John Paul Jones (ch. 9). History is thus presented as both 'from above' and 'from below'the official, history-book narrative is combined with non- or semi-literary forms of historical discourse.

Fanny is driven by "noble sentiments," both in rescuing her lover and in defending her country (Wheelwright [1995] 1996, 195). As the plot takes off, Fanny has to say goodbye to her love interest William, who has decided to make his fortune in the West Indies, which the narrator 
calls "the great American Archipelago" (Murray 1844, 17), in order to be able to marry Fanny; he now worries that she could be seduced by the loyalist naval officer Major Burnet in his absence. The following chapters alternate between William's and Fanny's stories: William's ship is captured by Caribbean pirates; he and two fellow sailors join the crew so as not to be killed, but plan to escape; the pirate crew is taken hostage by the Spaniards near Cuba, where William escapes, but is taken prisoner and suffers from ill treatment in Havana. Two years have passed when the patriotic Fanny learns about these developments from one of William's fellows (who has managed to break jail) and decides to free her lover; this she sees as her chance to see the world like William (12). She dresses as a seaman, calls herself "Mr. Channing" and is hired by the British privateer Constance, about to venture off into the Caribbean.

Soon the crew, described as almost exclusively "Americans," mutinies against the tyrannical captain who plans to press them into the King's Navy for monetary reward. Fanny/Channing sees it as her/his patriotic duty to protect her fellow American citizens from the fangs of Great Britain:

The North American colonies were then at war with the mother country, the brig was a British brig, and Channing was an American. His heart beat warmly for the cause of his country, he looked about him, there were twenty men, all save one, his fellow countrymen, about to be betrayed into the hands of their enemies. His mind was determined, and he said within himself, this shall not be! (31-32)

Thus s/he takes the captain hostage during the mutiny, "determined that the good brig Constance should change hands, and from a British, become an American craft. It was a bold undertaking; the two greatest sins that a sailor is taught to dread, mutiny and piracy, were staring him full in the face" (32). Fully conscious of the illegality of her plans, Fanny/Channing nevertheless is shown as pursuing them as necessary and legitimate acts in the fight against colonial oppression and national as well as personal impressment-pointing to debates about the legality of enslavement at the time Fanny was written and thus arguably, albeit implicitly, promoting 'illegal' acts of resistance. Her crew supports her, but in a forecastle debate about their legal status also argue against being categorized as pirates. One sailor contends that they are engaged in an "honest war" against Britain rather than in acts of plundering that do not 
differentiate between friendly and inimical nations: “'Ain't the Colonies honestly at war with the English? And have we been cruising against any other nation but them?"” (60). At an earlier point, the narrator states his agenda even more clearly, announcing that "we shall see that Channing was fully justified in the capture" (34) of her first prize. Indeed, the novelette's use of the term "pirate" when it in fact continuously disavows this criminal label is crucial for a contrapuntal reading sensitive toward the fact that this confusion is indicative of the categorical crises it negotiates.

The crew is enthused with its new captain, who is described to combine masculine and feminine virtues: "although his orders were given in a prompt and decided tone, and implicit obedience was exacted, yet was his voice musical and kind, and his orders were almost anticipated by the promptitude of the willing crew, who soon came to love him for the generous consideration he evinced for their good and that of the vessel" (27). Liberty and freedom of choice are emphasized time and again as moral virtues worth fighting for, for example when Fanny/Channing offers her fellow sailors the free choice of whether they want to stay aboard or disembark; after all, according to British law, they are mutineers on a piratical expedition, facing the death penalty if captured.

Before reaching Cuba, they seize a British ship in their first battle. Again, this act of piracy and capture is justified by the narrator's retrospective commentary on the Revolutionary events and "the hardships and vicissitudes of a people struggling for freedom, and of the almost incredible sufferings cheerfully endured by all in furtherance of the great and holy cause in which they had embarked" (40); the "holy cause" (71) transcends the law and turns piracy into a legitimate strategy in the battle against colonial oppression. In line with the foundational Puritan myth of America as a "City upon a Hill" (John Winthrop), the American project is presented as sanctioned by God, who, like the pirate, is also beyond human law. Interestingly, the capture is presented as without historical precedence in an imperial discourse that popularized the idea of filibustering in the Caribbean in the service of manifest destiny (Woertendyke 2013 , 215). Fanny, patriotic rather than piratical, is credited with making maritime inroads for the United Colonies:

the proud flag of St. George was lowered to the pine tree of the American colonies. This was one of the earliest, if not the very first capture upon the high seas, so far from our own country, by the humble but victorious flag of the colonies. It was then a child, it is now grown to the full stature 
of a man, and floats proudly in every sea, and undaunted, side by side, with equal honor and equally respected with that of the mother country. Who could have foretold its future glory and power? Those who fought under that flag, little dreamed of it, but Heaven was with the right, and they were victorious. The pride of the parent country was to receive a fall, its arrogance was to be signally reproved and this was to be done by her dependent colonies of North America. It was done! ... The pine tree flag had never before floated in the seas of the West Indies and captain Channing's hand was the first to give it to the breeze, and fight under its folds, in those seas of perpetual summer. (36)

The text's repeated emphasis on the hissing of the American flag is reminiscent of the performative act of territorial appropriation through symbolic gestures (planting flags, signing treaties) in the European legal/colonial tradition, bestowing a legal title to land as if that title were available to conquer, while in fact creating such legality through the very act (Derrida 1986). Also, the Black Legend is affirmed by portraying the Spanish colonizers as rough and lazy (Murray 1844, 35) and the Cuban Governor General as an "old tyrant" (21); in addition, Fanny/Channing's motivation for her Caribbean expedition exceeds love, including fame and fortune as well. Thus Murray's pirates are constructed not as absolute outlaws, but as figures on the brink of legality, signifying legitimate antecedents to nineteenth-century expansionists. In line with this evocation of the colonial tradition, another 'first' is mentioned here: Columbus, one of the most important mythological figures in the first half of the nineteenth century in the construction of a genuine American past (Paul $2014,50-58$ ), is being called upon as a figure of identification in the Cuba episode: "You are carried back in your imagination to the time in which the weary watching barque of Columbus was first cheered by the soul thrilling cry of, 'Land ho!' And when the gallant adventurer and discoverer rested in peace before the sunny isle of Cuba!" (Murray 1844, $21)$. The island itself is represented as yet another tropical paradise of eternal summer:

The mild and beautiful climate of Cuba seems more like the elysian fields of poetic birth, than the air that forms the islands of the ocean. Beautiful indeed is the genial influence of the mild zephyrs that breathe over these pacific seas. ... The tall, majestic palm, and other tropical trees; the genial softness and beauty of the foliage and verdure; the rich glowing sky and 
fervid sun, all serve to remind you that you are in a land of perpetual summer. (43)

This extension of the U.S.-American sphere of action, the description of the island in terms of a colonial hermeneutics, as well as the evocation of Columbus and the representation of the Spaniards as tyrannical colonizers, oppressing Cuba similar to the British in North America, partakes in the fledgling discourse of American imperialism, bringing it to a mass audience. The heroine personifies an avant-garde American imperialist: Anderson calls her a "soft conquerer" (2011, 105), and Woertendyke views her in the context of a "hemispheric regionalism" $(2013,212)$ that constructs Cuba as "naturally" belonging to the "North American Republic" (214), though Fanny is mainly shown as a relentless agent for the cause of American Independence (paralleling her advertising of women's independence to enter masculine spheres of action). ${ }^{30}$

In Cuba, the crew frees William, who soon recognizes Fanny, but does not uncover her disguise. Fanny/Channing, however, does not behave as a captain to a crew-member (William is her first mate, in fact), but as the female part was expected to in a nineteenth-century romantic relationship: she seeks William's permission for her actions and even then subjects her authority to William's (Wheelwright [1995] 1996, 195), thus restoring gender hierarchy. In the following, the Constance, hissing the pine tree flag, seizes another British vessel and one of their prisoners tries to incite a mutiny. The crew sentences him to death, but Fanny/Channing decides to convince him of the American cause instead, which she manages to do by employing both the enlightenment value of reason, connoted as masculine, and the feminine virtue of kindness: "A stubborn spirit was conquered by kindness and reason, the only weapons that one responsible being should use with another. The Englishman's spirit had undergone a complete change; ... and from the hour of his liberation, was an ardent supporter of the cause of the American people" (Murray 1844, 57). Fanny/Channing is represented as masterful in controlling her own emotions as well as in governing others', and her reason and judgment are unfailing throughout the novelette (De Grave 1995, 250). Both Fanny and her alter ego Channing are constructed as embodying a third, though provisional, gender, imagined as an amalgamation of the most important feminine and masculine attributes.

In the bay of Cape Cod the reader witnesses a final battle with a British ship, led by Major Burnet, who is victorious and asks Fanny to marry 
him after he discloses her disguise. Fanny refuses, which leads Burnet to attempt rape, but she manages to escape and returns home, where she finally marries William. For the duration of the American War of Independence, they continue their maritime plundering of the enemies of American independence together. Peace returns to what is now the United States; at this point, the narrator comments upon the subsequent rise of the United States well into the nineteenth century in the biologistorganicist language of natural (male human) development, insinuating (imperial) growth as an organic process. The process of emancipation from the British, "stymieing the US's 'natural growth"” (Anderson 2011, 103 ), is likewise cast as "natural":

the bond was severed, the child sprang at one to the estate of manhood and to all its responsibilities and cares; but it was under the divine guardianship of the spirit of peace and the especial guidance of Freedom herself; with such patrons she was sure to prosper, and how she has prospered, let the present state of the Union bear testimony. ... From a tender plant as it were, we have grown to a large and powerful oak, whose branches are spread far and near, and under whose shadowing protection millions may shelter. (Murray 1844, 81)

The oak spreads its branches far and near: from the Revolutionary period, a history of national growth and expansion is projected in this quote, ending in the imperial present of the 1840s; a decade also of mass immigration, as the "shadowing protection" under which "millions may shelter" hints at. Indeed, immigration and expansion are linked together here as two sides of the same coin of expansion, true to the history of U.S. settler colonialism and frontier expansion.

Similarly, Fanny Campbell's final transformation from pirate captain and Republican heroine into a domestic woman and mother testifies to the narrative's shift to the (mid-)nineteenth century and its restrictive gender discourses. Fanny longs for the sea, but instead of continuing her maritime life she undertakes a farewell cruise with William in a fully furnished and widely admired "pleasure yacht" (82), The Vision, equipped with upholstery, cushions, and draperies, "in as good taste as in her parlors at home."

The transgressive mobility of the female pirate is transformed into that of the imperial tourist, and accordingly, the voyage first takes them back to the Caribbean Sea, "drawing forth fresh interest and an increased desire 
for exploration" $(81)$ and then to the classical tourist destinations of the 1840s: the Mediterranean and Italy as well as the Channel Islands off England. A visit to a fisherman's family seals Fanny's transmogrification, as she confesses to William: "I should be happier now, had I never have mingled in the strife of the world, if I could have lived retired with thee, from all its contentions, and only have known by experience of thy love and kindness" (89); even William's cheering words ("you have done the part of a hero, and have nothing at all to regret. I declare, I envy you") do not help: "Fanny missed the calm and peaceful joys of a quiet and retired life" (92). The narrative voice comments that the excursion to the fisherman's hut is supposed to draw an image of peace and happiness with a moral aim, and in line with this, the conclusion mentions that Fanny became a mother of two sons, who both embarked on a career in the American Navy, and that she now inhabited an estate, given to the couple as remuneration for their merits in the War of Independence, in Salem (notorious for the disciplining of femininity since the Puritan witch-hunts of the 1690s).

Last but not least, the narrator does not shy away from revealing the intentions behind the tale presented: "We have endeavoured in Fanny Campbell to portray a heroine who should not be like every other the fancy has created; we have strove to make her such a one as should elicit the reader's interest, and have yet endeavoured in the picture not to overstep the modest bounds of nature" (99). The Vision refers also, then, to foresight in terms of the development of normative American femininity in the nineteenth century, as the narrator, with Fanny, turns to "the sweets of domestic happiness" (79), refers to her as "wife" frequently in the remaining narrative, and emphasizes her Christian piety (89). However, the narrative's didactic intent with regard to the "normalization" of rebel femininities is undermined by the larger-than-life characterization of Fanny and the popularity of female cross-dressing since the eighteenth century in Atlantic popular culture. In this sense, the sign of piracy betrays a discourse of nostalgia disturbing any smooth transition from a cross-dressing pirate captain to "angel of the house."

\subsubsection{Female Pirates and Cross-Dressing Women Warriors}

In Fanny Campbell, the sea is primarily a site of play and potentiality (Woertendyke 2013, 223) with regard not only to heroic piracy, but equally to gender performance. Female pirates and cross-dressing sailors 
had a long and deeply rooted tradition around the Atlantic world for centuries, both as historical figures and as larger-than-life characterizations in ballads - the so-called "female warrior ballad" (Dugaw 1996; Wheelwright 1994, 8) - and a number of other (semi-)literary forms catering to a "semi-literate working class" (Rediker 1996, 11). Ever since Captain Johnson had made popular the lives of Anne Bonny and Mary Read in his General History, female seafaring and piracy were themes in print and on the stage as well as in oral culture-in Britain, most famously in John Gay's satirical ballad opera Polly (1729), the widely successful sequel to The Beggar's Opera (1728) featuring a cross-dressing heroine who joins a group of pirates in the West Indies in search of her husband, ${ }^{31}$ and in the United States in the Female Marine trilogy (18151818), the fictional story of a young cross-dressing woman serving on the U.S. frigate Constitution in the War of 1812 , which ran through nineteen editions within just four years (Cordingly [2001] 2007, 52-53; Cohen 1997). The fascination with Bonny and Read, especially among female readers, rested upon Johnson's and others' representations of them as taking "part in a utopian experiment beyond the reach of the traditional powers of family, state, and capital, one that was carried out by working men and at least a few women. They added another dimension altogether to the subversive appeal of piracy by seizing what was regarded as male liberty" (Rediker 1996, 15). Similarly, in a chapter of his classical study Virgin Land: The American West as Symbol and Myth (1950) entitled "The Dime Novel Heroine," Henry Nash Smith mentions Fanny Campbell as evidence for the transformation of the genteel heroine to fit a harsh American environment by means of cross-dressing in the nineteenth century ([1950] 2009, 112). Writing in the context of an American exceptionalist narrative, however, he turns a blind eye to the transatlantic dimension of this development (see also Anderson 2011, 95).

Both Anne Bonny and Mary Read's stories, as made popular in Johnson, reverberate in Fanny Campbell. Read's life, qua Johnson, by the time of her trial, "had changed dramatically; she was heavily pregnant, deeply in love and her desire for a quiet life appears more believable ... [. A]n exceptional woman, glorifying masculine values, finally returns to her appropriately self-sacrificial maternal role" (Wheelwright [1995] 1996, 184); Bonny was American-born (although of Irish immigrant stock rather than New England Puritan heritage) and, like Fanny, went to Cuba to be with her lover, pirate Captain Jack Rackham, aka Calico Jack (188; Cordingly [2001] 2007, 79-87; Defoe/Johnson [1724] 1999, 
153-65). As Johnson's renderings inspired a plethora of popular (often ephemeral) literary and oral forms, the "idea that women could be searovers was enshrined in popular ballads and dramas of the eighteenth century which celebrated the feats of cross-dressed women (even if some did come to terrible ends)" (Stanley 1995, 42; Dugaw 1996). Fanny can be placed in this tradition of the "female warrior" genre that had emerged from a late medieval world in transition to the modern (Dugaw 2010, 274), following its conventions closely: it borrows its episodic structure and roguish protagonist from the picaresque, features romance elements (especially the heterosexual love story) and standard tropes such as "the heroine's independent spirit; her masked pursuit of a husband or lover; ... proofs of her service and valour" (292), as well as a play with samesex desire. This can best be seen in the dialogue between the lovers upon William's departure: Fanny states that she "env[ies him] the experience ... of the world" (Murray 1844, 12), which William finds strange; she thus asks him if he loves her any less for her manly aspirations, to which William replies: "No, no, my dear girl, I only love thee the more, while I am still more surprised at thy brave and noble spirit, at thy judgment and thought that characterises one of thy sex and tender years. By my soul thou shouldst have been a man, Fanny."

While Dugaw (2010) argues that such outlaw "heroines"-regardless of their limitations as models of liberation-had given way to more docile models of femininity by the early nineteenth century, Rediker insists that figures like Bonny and Read continued to inspire young women to try alternative paths of life, citing also the work of Julie Wheelwright, who demonstrates that the historical and fictional figures of the female soldier and sailor were important to nineteenth-century feminists in that they disproved the prevailing assumptions regarding women's incapacities, physical and mental. Indeed, cross-dressing heroines continued to be common in popular fiction in the second half of the century (Anderson 2011, 95; Smith [1950] 2009, ch. X). Both Dugaw and Rediker have a point with regard to Fanny, whose conservative remodeling of a transgressive figure answers the prevalent "woman question" by relegating subversive images of femininity to their 'proper place' of home and hearth but at the same time rekindled the memory of former popular heroines less domestically inclined, as by that time "[b]alladeers and novelists worked to shape the female tar into a more acceptably feminine form by couching her story in the melodramatic conventions of contemporary literature" (Wheelwright [1995] 1996, 194). 
One of the few examples of a documented contemporaneous female reader's response to Fanny Campbell is that of the Canadian Sarah Emma Edmonds, who, disguised as a man, escaped from her father's home in New Brunswick, Canada, in 1854 and participated in the Civil War as part of the Second Michigan Volunteers under the pseudonym of Frank Thompson (E. Young 1999, 144-45; Wheelwright [1995] 1996, 196). In Edmond's autobiographical narrative Nurse and Spy in the Union Army (1865), she relates that reading Fanny Campbell represented the turning point of her life after her mother gave her the book at age thirteen; the scene in which Fanny cuts her hair and puts on the male sailor's garb, "stepp[ing] into the freedom and glorious independence of masculinity" (quoted in E. Young 1999, 155), inspired her as a girl to swear that one day she would do the same, although she scorned Fanny's motive of rescuing her fiancé (De Pauw 2000, 153; Cohen 1997, 9). Not only as a patriotic narrative of piracy, but also as part of the "female warrior genre" that was very popular in the 1840s, Fanny's domestic ending does not seem as memorable as the protagonist's adventures in the male sphere of action to female readers such as Edmonds. Following Holly Kent, "female readers ... had the power to make the (essentially conservative) pirate novels into radical texts, ignoring the heroines' inevitable submersion in the home, and finding inspiration in their performance of roles not meant for women, in a world reserved for men" $(2008,57)$. Historical cross-dressing warrior women "co-existed with their representational counterparts" (Dugaw 2010, 276; also Wheelwright 1994,8$)$, traversing one more categorical boundary by blurring the factual and the fictive ${ }^{32}$ : models for Fanny can be found in those crossdressing women who had fought as soldiers in the Revolutionary War, such as "the Universal Female Patriot" (Fitz 2010, 241) Molly Pitcher or Deborah Sampson, a soldier in the War (Karl 2011, 33). It is no coincidence that the popular Molly Pitcher figure also appears in Fanny: known from popular poetry and melodrama at the time and modeled after Moll Dimond Pitcher, the fortune-teller of Lynn "whose special province was the sea" (Thompson and Schaumann 1989, 15), she was famed among sailors and ship owners from near and far and thus initially called Captain Molly (before she was tamed into a more genteel figure; Raphael 2004, $34,40)$.

Cross-dressing, as Jo Stanley has explored, played a significant role in the representation of female sailors and pirates. She argues that this 
tradition is mostly "an expression of the [usually male author's] narcissistic assumption that men are the prototype and women the adaptation, the piratess, the mini-version of 'proper' male pirates" $(1995,45)$, even though she admits that historically, cross-dressing usually had pragmatic reasons for women-travelling safely, avoiding molestation, and a less restricted mobility (44) - and women pirates in particular, whose adoption of the "informal pirate uniform ... would have been essential to their authority" (46). In the same vein, she contends that the female leg, emphasized by wearing trousers, is part of a fetishistic image of women, implying "an animal sexual availability, especially outrageous and exciting in the Victorian period when even piano legs had to be swathed for fear they would incite lustful thoughts." Cross-dressing female characters, Stanley suggests, are sexualized objects of male desire, the narrative taming their transgressiveness: "Women who behaved in this way had to be captured and their gaze adjusted; perhaps in writing about women robbers and transgressors, men were metaphorically taming them and restoring the approved balance" (59). Captain Johnson, long before the cheap romance novelette appeared, ensured "that the [cross-dressing] women [pirates] are portrayed as equally feminine by fleshing out stories of their romantic encounters" (Wheelwright [1995] 1996, 183).

A similar restoration of balance is at work in Fanny Campbell. Echoing Marjorie Garber's theory of cross-dressing (see below), the narrative compensates for the protagonist's outlaw femininity by rendering her cross-dressing a temporary response to personal and political crisis-the imprisonment of Fanny's romantic interest William and the War of Independence; it is first and foremost an act of patriotism. The radicalness of the text's repeated questioning of gender norms is countered by frequent descriptions of her feminine features (such as her musical voice and her "full and heaving breast," 15), but also intermedially by the colored frontispiece adorning the novelette (Fig. 2.1), as it counterbalances implications of immorality-her legs are clad in tight-fitting pants-not only by choosing the color white, with its conventional connotations of innocence, virginity, and purity (the latter being one of the cardinal virtues of the nineteenth-century "true woman"), but also by her stately posture, her uniform, and the holding of the jolly roger flag, presenting her like an official: the narrator indeed describes her "blue sailor's pants, and a short Pea Jacket [the jacket traditionally worn by sailors of European and American navies] descending about half way to the knee" on her armed body, so that she looks like "a king's officer in disguise" (26). The jacket in 
the image is notably lengthened into a close-fitting, waisted coat girthed to almost resemble a dress, reaching nearly to her knees. Her neat headdress, make-up, the feathered red hat and the stainless white blouse also water down the act of cross-dressing. And while her trousers (reminiscent of the sansculottes marking the working class in the French Revolution) symbolize movement, in line with “... many popular nineteenth-and twentieth-century images [which] show their [i.e., female pirates'] legs ... active-fighting, walking, lunging, standing threateningly" (Stanley 1995, 46), Fanny's feet in the image are tiny, again attenuating the radical potential of the cross-dressed heroine as opposed to the narrative description of her feet (Fig. 3.1).

The visual representation of Fanny thus references iconic images of cross-dressing female warriors such as The Female Marine in this ambivalence toward cross-dressing, female empowerment, and mobility (Cohen 1997, 27). The ambivalence of the cross-dressing female pirate, created intermedially by diverging narrative and pictorial signs, is also reverberant in critical interpretations of this figure: both Stanley and Wheelwright assert that female pirates were fictional(ized) figures of transgression and empowerment for their female readers, but at the same time read crossdressing stories as rather tame and limited in their subversive potential: on the one hand, "female swashbucklers of popular literature provided an alternative image of women and inspired others to challenge the rigid definitions of sexual difference" (Wheelwright 1994, 13-14), but on the other " $[\mathrm{c}]$ ross-dressing for women often remained a process of imitation rather than a self-conscious claiming of the social privileges given exclusively to men for all women. Their exploits challenged existing categories of sexual difference but the terms of the debate usually remained the same" (11). ${ }^{33}$

Indeed, this ambiguity is at the very heart of representations of female pirates and other cross-dressing outlaw femininities at that time, echoing the fact that definitions of class and gender were in transition; Dugaw notes that "the cross-dressing female warrior ... flourished when ideas about human sexuality and what we call gender were shifting" (2010, 288). ${ }^{34}$ Tales about cross-dressing symbolically reproduce such a crisis in the gender category; the urge to "normalize what the women have done by giving reasons for their behavior is a reaction to that crisis" (De Grave 1995, 118). Whether subversive or affirmative of prevailing gender norms, Fanny, through its portrayal of female involvement in the Revolutionary War, voices the mid-nineteenth-century contradiction between 


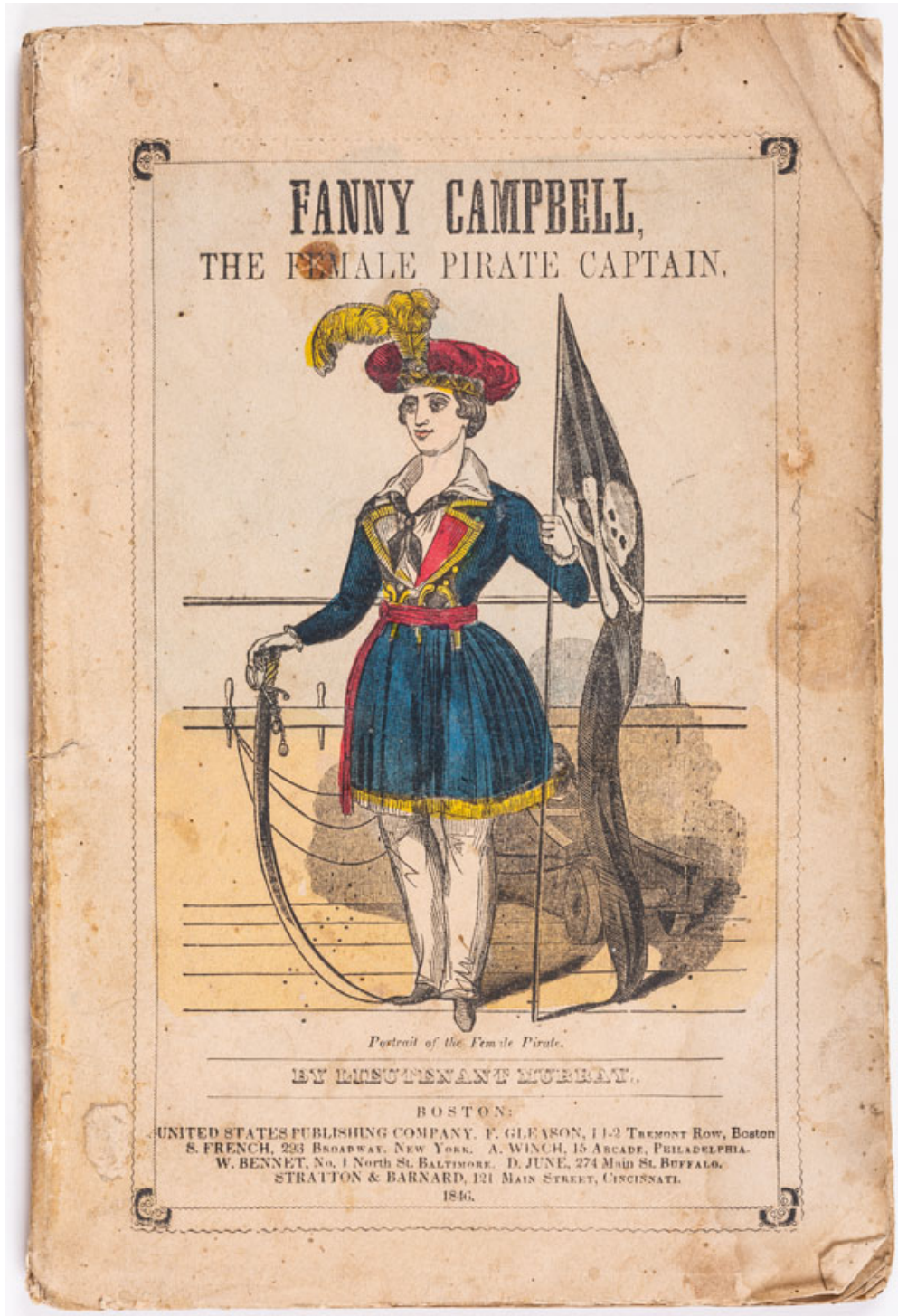

Fig. 3.1 The title page of Fanny Campbell, The Female Pirate Captain (Courtesy of American Antiquarian Society) 
women's confinement to domesticity and their increasing public presence (Fitz 2010, 221), reviving models of femininity from before the "backlash" (as the transition from Republican Motherhood to the "cult of true womanhood" is often referred to). Representations of active women in the public sphere

... have to be read alongside those which reconfirmed the beliefs of the cult of domesticity and, of course, alongside such documents as the Declaration of Sentiments. These images of active female involvement and patriotism contributed to create a new and more public domain for women. The ways in which they were ... commemorated were cornerstones in the process of redefining the female sphere-and thus gender concepts as such .... (Fitz 2010, 264)

\subsection{5 "Crises Elsewhere": Class, Citizenship, Ethnicity, and Race}

The central place that cross-dressing and travesty took in narratives about female pirates and other women warriors of the Revolution indicates, following literary critic Marjorie Garber, the crisis not only of gender roles and categorizations in any society, but of binary categories per se, visible in the usual confusions and mix-ups in stories of cross-dressers who "disrupt[] and call[] attention to cultural, social, or aesthetic dissonances" ([1992] 2012, 16). Garber views cross-dressing as an "interruption" (13) in binary thinking, ${ }^{35}$ a "putting in question" of binary oppositions that claim to be absolute. She insists that the cross-dresser introduces a "third" rather than affirming either the male or the female pole. This "third" introduces a crisis, Garber asserts, but is not itself a category or a "term" (11) but rather "a mode of articulation, a way of describing a space of possibility." In this way, the presence of cross-dressing may also indicate a category crisis elsewhere: "Category crises [i.e., "a failure of definitional distinction, a borderline that becomes permeable," 16] can and do mark displacements from the axis of class as well as from race onto the axis of gender" (17). She concludes that cross-dressing is not a cause, but a sign of crisis-and not "just another category crisis, but-much more disquietingly-a crisis of 'category' itself" (32; also 16-17; Cohen 1997, 28; De Grave 1995, 119).

In the case of Fanny Campbell, these scenarios of crisis "elsewhere" refer to a number of contexts in which comfortable socio-cultural binaries were disintegrating at mid-century. One was the changing class structure 
of American society and the concomitant desire of a rising middle class to find its symbolic place in U.S.-American society beyond genteel culture and high literature - to have heroes and heroines of their own, offering a potential for identification; from the 1840s, Karsten Fitz asserts, ordinary women engaged in the Revolution came to the fore in popular culture $(2010,263)$. The narrator emphasizes his democratic agenda with regard to class: "We have designed to show that among the lower classes of society there is more of the germ of true intellect and courage, nobleness of purpose, and strength of will than may be found among the pampered and wealthy children of fortune" (Murray 1844, 100). In addition, the prominent inclusion of lower-class cultural forms-especially tall tales, yarns, and mysterious stories in the vernacular-in sections in which the plot comes to a pause affirms their importance; he refers to Fanny as "our ill-spun yarn" (99) and in one of the implied author's metacommentaries toward the end of the novelette even disavows individual authorship, highlighting collective processes of story-telling. He claims that he is merely a listener and transcriber: "several of the yarns that are given here, are absolutely genuine ones, and mere transcripts as the writer has listened to them at sea; and also to refute in some degree the assertion which is so confidently and frequently made that these sketches are all humbugs, or originate entirely in the writer's fancy" (92). In a meta-commentary, he asks for the reader's moral judgment (despite his temptation to judge for them):

There is a moral that we are tempted to put down here, simple perhaps, but a great one nevertheless, yet fearing the censure of the general reader, who sometimes decries in no measured terms these moral digressions, we leave the inference to which we have only alluded, for the good judgment and discernment of the reader, but let us venture to urge its consideration. (57)

This flattering of the lower strata of society is of course also due to the addressees and intended readership of cheap popular novelettes, who shared Fanny's humble origins and experience of socioeconomic ascent (and through them were familiarized with both official American history and, through the protagonist's eventual conversion, to ideals of respectable, bourgeois femininity). The story hence "represented a particular working-class heroism ... in a period when definitions of class and gender had come more sharply into focus" (Wheelwright [1995] 1996, 
197). Yet this "heroism" is limited to "freemen," one has to add; at one point, the narrator puts the text's formal principle of including vernacular language and 'low' oral forms plainly: "Let the twenty millions of freemen who now people the land speak" (81).

The crisis indicated by the cross-dressing heroine relates even more prominently to citizenship and the nation itself, accompanying the concerns of territorial expansion and waves of new immigrants in the 1840s. In her monograph American Sensations: Class, Empire, and the Production of Popular Culture, Shelly Streeby discusses the significance of the so-called "story-paper literature" for cultural history, which represented a printing "empire" $(2002,83)$ and heralded a new era in American popular culture. In the specific contents of such publications at mid-century, the time of the U.S. invasion of Mexico and the Mexican-American War (1846-1848), Streeby diagnoses the waning of a postcolonial and the emergence of an increasingly imperialist politics and society in the United States. In this regard, Fanny Campbell seems to represent a transitional narrative: while its historical setting and plot focus on the (post-)colonial aspects of the battle for U.S.-American independence in the 1770s, its spatial setting and colonial hermeneutics, as discussed above, hint at the fledgling imperial interest of the time in territories south of the nation's border. The novelette thus combines the predominant craze for (mass-marketed) popular history (Pfitzer 2008), with the prevalent "structures of feeling" (Raymond Williams) of the time, which extended the U.S.-American sphere of agency (not least under Cooper's influence) not only along the western frontier, but also across the southern and maritime borders of the nation. Paradoxically, then, Fanny's Revolutionary piracies might be said to foreshadow future "piracies" of the American Empire in the Caribbean, not least by invoking the moral superiority of the nation (54). It affirms a foundational U.S. exceptionalism allegedly sanctioned by God and legitimizes American imperial interests. In her reading of Fanny, Katherine Anderson, focusing on the use of history in the novelette, concludes that it

allowed readers to envision a proto-national past in service of contemporary expansionist, or imperialist, ideology ... imaginatively mapping the Revolutionary moment-in which a barely viable entity fends for its right to nationhood against powerful old-world empires - on the mid-century present-in which the US was competing with those empires to secure its hemispheric status ... . (97) 
Anderson argues that the cross-dressed female pirate symbolized a nation that would never be able to "reach maturity (conceived of as manhood)" and that the novelette "evacuates historical discourse, failing to account for change in terms of human agency" by its very act of mapping the late eighteenth century onto the nineteenth. This argument may overstate the case-Fanny surrenders her position as captain (of the nation, in her logic) to William just in time to guarantee male leadership once the young nation is born, despite his "passive transition" (107) to that state; the amalgamation of past and present (which arguably happens in all historical fiction) does not necessarily deny the past, but might also hint at the interrelatedness, rather than chronological succession, of past and present histories. Yet Anderson's reading is right in emphasizing that the text reflects the expansionist ideology rampant since James Polk's presidency (1845-1849) and the Mexican-American War (101), especially by eventually imagining the ocean as a domestic space: "Fanny and William's wandering domestic space, mapping American feeling in places not (yet) American, constitutes something of an imperial gesture" (112) and eradicates the foreign element of the contact zone (113; Anderson calls this, as well as the form of the portable pamphlet novel crossing U.S. borders, "itinerant domesticity"). Hence the categorical crisis enacted in Fanny/Channing's piratical proto-imperialism pertains to the moment of undecidability in which the nation is imagined, paradoxically, as both colonized and colonizer, as past and future come together in the text.

The imperial transformations of antebellum America coincided not only with a critical state of the meaning of U.S. citizenship in the mid-nineteenth century (regarding the population of new territories, Native Americans-who appear in Fanny, as in Cooper, as remnants from the past and folk-tale figures only-and immigrants), but also with the increasingly radical debates about slavery in these decades. As it became obvious that the most dangerous scenario of crisis for the future of the Union was the debate over slavery and the status of each newly admitted state as slave-holding or free, ethnic and racial categorizations were being critically renegotiated everywhere in American cultural articulations, including popular literature. Fanny Campbell ties these debates together, significantly choosing Irish sailors as bonding figures: though marked by ethnic difference, they are brothers-in-arms who are assumed to have experienced a similar colonial abuse by Great Britain as their American brethren. The Irish are the only group exhorted explicitly to join the pirates along with the Americans after their capture of the British 
ship: "we only want our own countrymen, unless indeed it may be one of yours, who are most surely with us in heart at least" (40); an Irishman joins them consequentially. Yet the Irish characters are also portrayed as stereotypical simpletons, uneducated and entertaining through their accent and naiveté, but honest, faithful, submissive, and patriotic (e.g., the character Terrence Mooney, a member of Channing's crew; 40, 46). Not only was such prejudice against the Irish Catholics, the main group of immigrants since the 1830s, flourishing at the time (De Grave 1995, 139); the portrayal also echoes the intricate discursive relationship of Irish immigrants and blacks-especially African American slaves-Noel Ignatiev seminally explored in How the Irish Became White (1995), the story of how Irish immigrants developed from racially oppressed to oppressive. If Irish immigrants were not black in the 1840 s, they were also not quite white in contemporaneous racializations, that is, excluded from white (WASP) privilege (Halley et al. 2011, 72-74).

This ambivalence of ethnic/racial categorization is subtly reflected in the novelette, in which not a single African American character appears. Following Toni Morrison's argumentation in Playing in the Dark: Whiteness and the Literary Imagination (1992), Fanny can be read as substituting prevalent discourses about African American enslavement in the 1840s with a number of adjacent discourses, simultaneously denying and affirming the presence of blacks and of racial tension in a nation idealized as the natural habitat of liberty: discourses about the Irish and their ethnic/racial and national status as formerly oppressed, (nonwhite or not-quite-white) colonial subjects and future (white) Americans; about the practice of impressment, which is critiqued as "a foul deed" ("It is a foul deed to impress a man into any duty, and foul must be the service that requires the exercise of such deeds," 26); about the oppression of the American colonies by the British Crown and their "struggle for freedom" (40); and, finally, about the discourse of crossdressing in the sense of blackface, as Fanny is also shown to be navigating along the color line (Garber [1992] 2012 calls this "Cross-dressing the Color Line" in the subtitle to chapter eleven). Her hair is described as "very dark auburn" and "naturally curled" if "left to itself" (15), mixing Irish and African features, and her skin color as very pale in the beginning (26) but increasingly becoming, after her transmutation into Channing, a "darker hue" (47; this, of course, is consistent with the effects of a sailor's exposure to the sun), "as dusky as a Negro" (48), though William denies that he would ever have "suspected" her to be 
"colored." Fanny/Channing reports s/he is considered "rather dark for an American" (45) and then admits: "It is a stain put on for a more perfect disguise" (46). Fanny/Channing, in this way, transgresses both gendered and racial borders as a pirate captain on a mission equally romantic and patriotic.

Despite its limited appeal to "freemen" only, Fanny Campbell, by repeatedly calling upon the opposition between oppression and freedom, projects this opposition back to Revolutionary times and thus contrapuntally establishes an analogy of discourses that links the Revolutionary cause of colonial emancipation with nineteenth-century demands for freedomfor and by both women and African Americans. ${ }^{36}$ This is also evident in Sarah Edmonds' account of her reaction to the novelette, retrospectively combining the concerns of both the women's and the abolitionist movements: "All the latent energy of my nature was aroused ... each exploit of the heroine thrilled me to my fingertips... I was emancipated! and could never again be a slave" (quoted in Kent 2008, 57). ${ }^{37}$

\subsubsection{Fanny, the Patriot}

In sum, Fanny Campbell suggests a linear history of American freedom that renders the fight against oppression a patriotic duty justifying, even demanding, the overstepping of legal boundaries. Not only the transgression of these, but also of boundaries between masculinity and femininity are legitimized as a "noble" and necessary response to crisis, echoing Marjorie Garber's observation in the context of her discussion of Anne Bonny and Mary Read that "the borderline life of a pirate, sailing on the windy side of the law, marks a crossover occupation that suits [Bonny's and Read's] gender histories - or at least the desire to narrativize them" ([1992] 2012, 181). The pirate, as a borderline figure, can be read as doubling the cross-dresser's ambivalent epistemological status; indeed, pirates are narrative constructs sharing with the cross-dresser the provocation of epistemological insecurity (Murray 1844, 16) - it is no coincidence that "dressing up" was noticed as pirate behavior since the seventeenth century (Garber [1992] 2012, 180-81; also Karremann 2011).

The narrative of the cross-dressing pirate in Fanny Campbell dramatizes the crisis of legitimacy and the nation's ambivalence in coming to terms with its past (Anderson 2011, 99) —and its future, one could add. It is not just a text about a general notion of piracy, but functions only in 
the context of the myth and romance of American history that the novelette affirms (see also Woertendyke 2013, 217). Indeed, it is then not a narrative that heroizes piracy per se, but rather limits its legitimizing discourse to "this pirate of a rebel" (68): a revolutionary, patriotic crossdressing pirate in the service of the American nation. Katherine Anderson, noting that Fanny acts "during the transition of legal authority from one government to another" $(2011,105)$, draws attention to the fact that legal authority in Fanny is in limbo; the provisional status of the pirate, who "can be simultaneously hailed as a national hero and distanced from the nation as a juridical entity" (106) echoes the provisionality of Channing/Fanny's masquerade. In the book, this double provisionality paradoxically assures Fanny's - and, allegorically, the nation's-liberty:

Some fears were entertained by Fanny and her family, touching upon the captures she had made, inasmuch as strictly speaking she had laid herself liable to the charge of piracy! And Fanny, in the eyes of the law, was actually a Female Pirate Captain! But there were none to prosecute such a charge, and if there had been, Captain Channing could no where be found. (Murray 1844, 79)

In the text, the mythology of American freedom not only obscures, but also attempts to solve a crisis of legitimacy, personified by a cross-dressing pirate, by (re-)integrating her into her fictional society and its normative gender structure as well as the national narrative. The crisis of U.S. legality indicated by the use of the term "pirate" is resolved by a discourse of American patriotism; in the end, piracy is consequentially externalized: "The ocean is the place for excitement ... . You have the storm to contend with, and happy are you if you master it in room of becoming its victim. You have tides and currents to watch, winds ..., and not unfrequently some daring rover to repel” (82). The process of incorporating the pirate into a U.S.-American national narrative thus happens on two distinct temporal levels in Fanny Campbell: first, in the context of the American Revolution, which, by the 1840s, had already been patriotically legitimized in American culture; and second, at the time of writing the novelette in preparation of an American Empire that needed to make use of such patriotic feelings about "pirates" in the ongoing process of legitimizing territorial expansion: "the narrative, its characters, plot, and motifs are poised to move across water, releasing space-time connection with U.S. national history" and "a sense of simultaneity, as American 
revolutionary zeal is sutured to Cuban piracy, Spanish imperialism, and U.S. maritime space" (Woertendyke 2013, 220).

However, as I have argued in this chapter, the eventual pacification of the text's unruly aspects, even radicalness in some of its commentaries, is disturbed by its counterpoints: first, U.S.-American piracy is relegated to the past, but the imperial gestures indicate its present function as a sign of empire; second, the cross-dressing heroine is brought back to domesticity, but, as Edmonds' reading response plausibly suggests, is less memorable to female readers than her escape from home and hearth; third, the lower-middle class, including recent immigrants such as the Irish, finds its symbolic place in the national drama, through the propagation of vernacular and folk cultural forms in this mass-market product, and is integrated into the myth of the American dream by portraying Fanny's eventual social ascent-but while the Irish are "becoming white," the crisis over slavery, which the text attempts to (but cannot) ignore, continues to haunt both the narrative and the nation. Consequentially, the sign of the pirate reappears in the context of the crisis over slavery and the Civil War.

\section{Notes}

1. This had to do with the fact that the U.S. itself, Adams continues, was "from the first a creature of law. Its birth was a legal act; the Declaration dissolved an old contract, and the Constitution created a new one" (1990, $5)$.

2. Identity in the antebellum context is conceived as a "condition involving the relations of the self with external structures of authority, rather than the sort of self-integration more modern ears may her in the word" (Adams 1990, 18). The periodization of 'Antebellum America' is debated by historians; I am adopting a broad view for my study, taking the Missouri crisis as anticipating sectional conflict that would eventually lead to the Civil War (Bowman 2010, 1).

3. Green adds that Tocqueville took the same position in 1835 when he remarked that Americans were born to rule the seas "as the Romans had been to rule the world" $(1978,168)$. It is remarkable that this aspect of the American historical imagination has been much less explored than the western frontier paradigm.

4. Comparative studies of Scott and Cooper reach back to the nineteenth century, when the nickname "the American Scott" was already in use (and vehemently refused by Cooper); the earliest study of influence (e.g., 
by George William Walker 1963) merely condemn Cooper as an inferior Scott or collect lists of differences (usually attributed to the different American environment and the experience of conquest) between the two.

5. I consulted the U.S. edition of Dekker's study, published in the same year, which is subtitled "The Novelist" instead of "The American Scott."

6. For a critical discussion of early American literature as a postcolonial phenomenon, see Buell (1992) and Davidson (2004, 13-24). While it can be useful, following Gesa Mackenthun, to take a postcolonial perspective on early American literature, it is of course dangerous to forget that the United States has always been both postcolonial and colonizing, "heir to the policy of British imperialism" $(2004,6)$.

7. Shubrick (1790-1874) served in the War of 1812 and the MexicanAmerican War and retired early in the Civil War.

8. Contemporary readings in this context are concerned with Cooper's representation of the common sailor and the world of labor aboard ship: on the one hand, Cooper has been praised for inventing a genuinely American nautical realism that could not be found among his British predecessors such as Smollett and Defoe and for creating the sea novel (Walker 1963, v; House [1965] 1979, 129; Iglesias 2006); on the other, critics regard his fictional tars as exotic (rather than 'authentic') creations contemporaneous seamen allegedly found ridiculous, especially in terms of language (Anderson 1951; Berger 2009; Blum 2008, 72; for a more positive evaluation see Cohen 2008; Walker 1963, 8). Blum's study is especially worth mentioning here, as she demonstrates how Cooper ignores a plethora of factual narratives by sailors, strategically misrepresenting the genre of sea writing.

9. Barthes establishes this concept in "The Reality Effect" (1968), arguing that texts produce effects of reality: in the absence of any signified the textual signifiers standing in for 'reality' must rely on the concept of realism. He also shows that the effect of reality is a key problem in history, as historical writing, proclaiming an unproblematic realism, merely present this textual device in action ("The Discourse of History"). See Barthes (1989).

10. In a different vein, Reynolds interprets Cooper's romanticism and "[s]tylistic stiffness" in the 1820s as a "rhetorical defense against explosive forces within American popular culture" (1988, 186). In contrast, Heinz Ickstadt argued that Cooper "explicitly links the importance of literature to its popularity" $(1985,16)$ and used popular taste for instructive purposes.

11. On the role of Cooper's work in the transatlantic literary field of the nineteenth century and its active engagement with the relationship between America and Europe, especially Great Britain, see Buchenau (2002, 
esp. 68-70), Frank and Mueller-Vollmer (2000, ch. 6), and Boggs (2007, 61-89).

12. For more detail on Cooper and the American romance, see Dekker (1993).

13. See also Joseph Holt Ingraham's popular Byronic romances Lafitte: The Pirate of the Gulf (1836) and Captain Kyd (1839).

14. The name echoes the maiden name of Cooper's wife, Susan Augusta De Lancey, whose grandfather James De Lancey was a Royal governor of the colony (1753-1755) and his sons prominent loyalists during the War of Independence (while Cooper's forefathers fought on the opposite side).

15. Similarly, in a conversation with Gertrude about life at sea, Heidegger uses, according to the narrator, "irony ... concealed by playfulness," stating that " "... even I, confirmed and obstinate sea-monster as I am, have no reason to complain of your distaste for our element'" (Cooper [1828] 1991, 687).

16. During the height of the 'Reign of Terror,' the so-called 'furies of the guillotine' also wore red caps when they gathered around the guillotine to celebrate each execution. The guillotines themselves were painted red or made of red wood, and a statue of a woman titled liberty, painted red, was placed in the square in front of the guillotine. On the analogy of the French and the American Revolutions in this context, see Adams (1990, 88).

17. See McWilliams $(2004,1)$, echoing the subtitle of The Spy: A Tale of the Neutral Ground; the metaphor is highly problematic, especially if it is extended to the land, as it disregards the presence of Native Americans and other non-Anglo-Saxons, along with their legal and political systems, before the Revolution.

18. Neither Philbrick, who views The Red Rover as emblematic of Cooper's early renditions of maritime life in its "extreme romanticism" (1961, ix), nor Madison's exploration of Cooper's use of the Byronic pirate in The Wing-And-Wing (1996) take into account that the Byronic notion of the pirate was thus Americanized.

19. Cooper's readers have struggled much with assessing his representation of the U.S.-American revolution. While Peck (1976) emphasizes Cooper's ambivalence, Robert Clark draws a more negative picture; he explains that after 1776, radicalism threatened the nation's interests: "A society based on the universal right to life, liberty and the pursuit of happiness, and convinced of the right of its own citizens to possess what they have amassed, did not wish to remember that its Independence was achieved by subordinating its cherished principles to the higher ethical and pragmatic concerns of a violent revolutionary war" (1985, 202).

20. It might not be a coincidence, in Mackenthun's reading, that the Dolphin is masked as a British cruiser called Antelope during the final battle, citing 
the name of a slave ship apprehended by a U.S. cruiser in 1820 over whose human cargo a number of court trials were fought, ending in the 1822 Supreme Court verdict that the slave trade does not violate the law of nations (2004, 81-83). Mackenthun shows how Cooper's text, against all intentions, bears the traces of continuity between America's colonial past and its national future, e.g., also in the reversal of branding the skins of Africans with their owners' identities when it is revealed that Scipio tattooed "Ark of Lynnhaven" on Fid's arm after they rescued Wilder as a little boy from a wreck of a ship of that name: "Scipio Africa ... ensures with his écriture sauvage that colonial power relations will remain valid in the times to come" (83).

21. Similarly, Grenville Mellen objected to the Rover's portrayal in the North American Review: "There is too much poetry about him. It is not, in all respects, the natural character of a man who has so long led a life of peril and depravity, and spent the better part of his days in the reckless swing of desperation. There is, perhaps, too much of the genteel villain, and too little of the Ishmaelite, in his composition" ([1828] 1997, 147).

22. Some critics also see the divisive potential of this appropriation. In his monograph about memory and the American Revolution, Alfred Young (1999), for example, shows how various radical groups such as the emerging working-class movement and abolitionists started to claim the Revolutionary narrative in the mid-1830s for their purposes.

23. According to Wheelwright and many others, Fanny was first published in 1844 as The Female Pirate: A Tale of the Revolution of 1776 and later as Fanny Campbell, or, The Female Pirate Captain ([1995] 1996, 194). Page numbers in the following refer to the American Antiquarian Society's earliest edition (1844); spelling errors have been corrected for better readability.

24. The covers mention sellers in Boston, Buffalo, Philadelphia, Cincinnati, Detroit, St. Louis, Baltimore, and Louisville.

25. Reynolds (1988) calls this form a pamphlet novel rather than a novelette; Anderson uses both terms, as well as dime novel, interchangeably. I use novelette not only because Gleason's publishing house used it but also because the diminutive emphasizes the much smaller size and scale of these publications compared to the novels of the time. Dime novels proper first emerged with Beadle's Dime Novels as late as 1860.

26. Pfitzer (2008) analyzes the subscription sales techniques of book agents as well as the publisher's aggressive prepublication advertising campaigns, including the pictorial embellishments they employed as marketing devices (see also Reynolds 1988, 182).

27. The short prefatory poem must be understood in this context as a question concerning the novelette's generic textual economy: "When modesty's the rage, and love of change, / And things are doated on 
because they're / Strange / How shall he fare whose unaspiring hack / Jogs on the broadway and the beaten track, Leps o'er no moral fence, nor dares to prance / In the wild region of untried romance?" (Murray 1844, n.p.) The text answers the question by combining convention and sensation, as the narrator states through the voice of Captain Burnet: "Fanny, your story is a romance; no fairy tale could exceed it in extravagance, and yet it's all true" (76).

28. See also Anderson $(2011,110)$; she additionally mentions the travel narrative as another genre informing Fanny despite her diagnosis that the contact zone as the central fictional space is eradicated by the text's imperial politics.

29. Anderson $(2011,99)$ emphasizes the close similarity of Fanny's opening passage - the description of the geographical setting-and that of Scott's The Pirate (1822), a fact that highlights the continuing transatlantic character of pirate narratives, despite their nationalist politics, and introduces intellectual 'piracy' as another level of critique.

30. With regard to U.S. expansionism and the significance of female 'pirates,' cf. also the novelette The Female Land Pirate, also published by Gleason.

31. See, e.g., Rennie $(2013,84)$. Polly also references the eighteenth-century ballad of Polly Oliver, a female sailor (Wheelwright 1994, 15).

32. This blurring of boundaries is also a source of confusion for some critics, who seem mistaken to view Fanny as an historical character (e.g., De Pauw 2000, most recently Woertendyke 2013, 219-20); see Anderson (2011, 98 n. 6). To some extent, the story certainly does present a fictionalization of historical figures (e.g., Moll Pitcher) and events.

33. Elizabeth Leonard is less ambivalent in her judgment of Fanny as a model feminist, but can only be so because she, too, asserts a male standard, concluding that Fanny was "a worthy hero on all fronts" (1999, 250).

34. By the turn to the twentieth century, suffragists were taking an interest in cross-dressing literary women in order to argue for women's potential to fight in both military and political contexts (Wheelwright [1995] 1996, 197; 1994, 13). The protagonist's return to being Fanny, in addition, evoked her namesake, radical woman's rights activist and first female traveling lecturer Frances Wright (1795-1852), whose followers were slandered as "Fanny Wrightists" for decades (Karl 2011, 34).

35. In her discussion of Peter Pan, Garber quotes literary critic Jacques Lezra in this context, who, in a 1989 article on Shakespeare's Measure for Measure, asserts that the figure of the pirate is "the figure of interruption" ([1992] 2012, 181).

36. This is also evident in a scene in which she liberates one of her English captives, who is described in ways that evoke contemporaneous descriptions of African Americans: "broad and full across the chest, with heavy yet well formed limbs. His hair was short, black as jet, and curled closely to his 
head ... resembling a lion at bay, his huge, muscular form expanded with rage at the feeling of his bonds" (Murray 1844, 54). She lifts his death sentence, instead winning him over to support the colonies by reasoning with him.

37. Elizabeth Young interprets this invocation of metaphorical enslavement at a time when Edmonds was a girl, and therefore long before the Civil War, as proof that " $[\mathrm{t}]$ he American Civil War enters into this account as belated analogy, rather than patriotic catalyst, for her own 'emancipation'" (1999). Alice Fahs similarly sees Fanny as providing ways of imagining women's active participation in military-naval action on the eve of the Civil War (2001, 230).

\section{WORKS CiTED}

\section{Primary Sources}

Cooper, James Fenimore. 1828. Notions of the Americans: Picked Up by a Traveling Bachelor. Vol. 2. London: Henry Colburn.

- (1828) 1991. The Red Rover. In Sea Tales, edited by Thomas Philbrick and Kay House, 423-868. New York: The Library of America.

Defoe, Daniel [Captain Charles Johnson, pseud.]. (1724) 1999. A General History of the Pyrates. Edited by Manuel Schonhorn. Mineola: Dover.

Murray, Lieutenant [Maturin Murray Ballou, pseud.]. 1844. Fanny Campbell: Or the Female Pirate Captain. A Tale of the Revolution. New York: Samuel French.

\section{SECONDARY SOURCES}

Adams, Charles Hansford. 1988. "Cooper's Sea Fiction and The Red Rover." Studies in American Fiction 16 (2): 155-168.

- 1990. "The Guardian of the Law": Authority and Identity in James Fenimore Cooper. University Park: Pennsylvania State University Press.

Anderson, Charles. 1951. "Cooper's Sea Novels Spurned in the Maintop." Modern Language Notes 66 (6): 388-391.

Anderson, Katherine. 2011. "Female Pirates and Nationalism in NineteenthCentury American Popular Fiction." In Pirates and Mutineers of the Nineteenth Century, edited by Grace Moore, 95-116. Burlington: Ashgate.

Appiah, Kwame Anthony. 1995. "Race." In Critical Terms for Literary Study, edited by Frank Lentricchia and Thomas McLaughlin, 274-287. Chicago: University of Chicago Press.

Barthes, Roland. 1989. The Rustle of Language. Translated by R. Howard. Berkeley: University of California Press. 
Beard, James Franklin. 1976. "Cooper and the Revolutionary Mythos." Early American Literature 11 (1): 84-104.

Belasco, Susan. 2007. "The Cultural Work of National Magazines." In The History of the Book in America Vol. 3. The Industrial Book: 1840-1880, edited by Scott E. Casper, Jeffrey D. Groves, Stephen W. Nissenbaum, and Michael Winship, 258-269. Chapel Hill: University of North Carolina Press.

Bender, Bert. 1990. Sea-Brothers: The Tradition of American Sea Fiction from Moby-Dick to the Present. Philadelphia: University of Pennsylvania Press.

Berger, Jason. 2009. "Antebellum Fantasies of the Common Sailor; or, Enjoying the Knowing Jack Tar." Criticism 51 (1): 29-61.

Blum, Hester. 2008. The View from the Masthead: Maritime Imagination and Antebellum American Sea Narratives. Chapel Hill: University of North Carolina Press.

Boggs, Colleen Glenney. 2007. Transnationalism and American Literature: Literary Translation 1773-1892. New York: Routledge.

Bonner, Willard Hallam. 1946. “Cooper and Captain Kidd.” Modern Language Notes 61 (1): 21-27.

Bowman, Shearer Davis. 2010. At the Precipice: Americans North and South During the Secession Crisis. Chapel Hill: University of North Carolina Press.

Buchenau, Barbara. 2002. Der frühe amerikanische historische Roman im transatlantischen Vergleich. Frankfurt am Main: Peter Lang.

Buell, Lawrence. 1992. "American Literary Emergence as a Postcolonial Phenomenon." American Literary History 4 (3): 41 1-442.

Campbell, Mel. 2011. "Pirate Chic: Tracing the Aesthetics of Literary Piracy." In Pirates and Mutineers of the Nineteenth Century: Swashbucklers and Swindlers, edited by Grace Moore, 11-22. Burlington: Ashgate.

Clark, Robert. 1985. "Rewriting Revolution: Cooper's War of Independence.” In James Fenimore Cooper: New Critical Essays, edited by Robert Clark, 187-205. New York: Vision and Barnes \& Noble.

Clohessy, Ronald John. 2007. "Ship of State: American Identity and Maritime Nationalism in the Sea Fiction of James Fenimore Cooper." James Fenimore Cooper Society Miscellaneous Papers 24: 3-8.

Cohen, Daniel A. 1997. "Introduction." In The Female Marine and Related Works: Narratives of Cross-Dressing and Urban Vice in America's Early Republic, edited by Daniel Cohen, 1-45. Amherst: University of Massachusetts Press.

Cohen, Margaret. 2003. “Traveling Genres.” New Literary History 34: 481-499.

- 2008. The Novel and the Sea. Princeton: Princeton University Press.

Commager, Henry Steele. (1965) 1967. The Search for a Usable Past and Other Essays in Historiography. New York: Alfred A. Knopf.

Cordingly, David. (2001) 2007. Seafaring Women: Adventures of Pirate Queens, Female Stowaways and Sailors' Wives. New York: Random House. 
Davidson, Cathy N. 2004. Revolution and the Word: The Rise of the Novel in America. Exp. ed. New York: Oxford University Press.

De Grave, Kathleen. 1995. Swindler, Spy, Rebel: The Confidence Woman in Nineteenth-Century America. Columbia: University of Missouri Press.

Dekker, George. 1967. James Fenimore Cooper: The Novelist. London: Routledge \& Kegan.

- 1993. "James Fenimore Cooper and the American Romance Tradition." In James Fenimore Cooper: New Historical and Literary Contexts, edited by W. M. Verhoeven, 19-29. Amsterdam: Rodopi.

Dekker, George, and John P. Williams. 1997. "Introduction.” In James Fenimore Cooper: The Critical Heritage, edited by George Dekker and John P. Williams, 1-53. London: Routledge.

De Pauw, Linda Grant. 2000. Battle Cries and Lullabies: Women in War from Prehistory to the Present. Norman: University of Oklahoma Press.

Derrida, Jacques. 1986. "Declarations of Independence." Translated by Tom Keenan and Tom Pepper. New Political Science 7 (1): 7-13.

Dugaw, Dianne. 1996. "Female Sailors Bold: Transvestite Heroines and the Markers of Gender and Class." In Iron Men, Wooden Women: Gender and Seafaring in the Atlantic World, 1700-1920, edited by Margaret S. Creighton and Lisa Norling, 34-54. Baltimore: Johns Hopkins University Press.

. 2010. "Heroines Gritty and Tender, Printed and Oral, Late-Breaking and Tradition: Revisiting the Anglo-American Female Warrior." In Ballads and Broadsides in Britain, 1500-1800, edited by Patricia Fumerton and Anita Guerrini, 271-295. Surrey: Ashgate.

Egan, Hugh. 1995. "Cooper and His Contemporaries." In America and the Sea: A Literary History, edited by Haskell Springer, 64-82. Athens: University of Georgia Press.

Fahs, Alice. 2001. The Imagined Civil War: Popular Literature of the North and South, 1861-1865. Chapel Hill: University of North Carolina Press.

Fitz, Karsten. 2010. The American Revolution Remembered, 1830s to 1850s: Competing Images and Conflicting Narratives. Heidelberg: Winter.

Fluck, Winfried. 1997. Das kulturelle Imaginäre. Eine Funktionsgeschichte des amerikanischen Romans 1790-1900. Frankfurt am Main: Suhrkamp.

Frank, Armin Paul, and Kurt Mueller-Vollmer. 2000. The Internationality of National Literatures in Either America: Transfer and Transformation. Vol. 1: British America and the United States, 1770s-1850s. Göttingen: Wallstein.

Garber, Marjorie. (1992) 2012. Vested Interests: Cross-Dressing and Cultural Anxiety. New York: Routledge.

Green, Martin. 1978. "Cooper, Nationalism and Imperialism." Journal of American Studies 12 (2): 161-168.

Halley, Jean, Amy Eshleman, and Ramya Mahadevan Vijaya. 2011. Seeing White: An Introduction to White Privilege and Race. Lanham: Rowman \& Littlefield. 
Hobsbawm, Eric, and Terence Ranger, eds. 1992. The Invention of Tradition. Cambridge: Cambridge University Press.

House, Kay Seymour. (1965) 1979. "The Unstable Element.” In James Fenimore Cooper: A Collection of Critical Essays, edited by Wayne Fields, 129-144. Englewood Cliffs: Prentice-Hall.

Ickstadt, Heinz. 1985. "Instructing the American Democrat: Cooper and the Concept of Popular Fiction in Jacksonian America." In James Fenimore Cooper: New Critical Essays, edited by Robert Clark, 15-37. New York: Vision and Barnes \& Noble.

Iglesias, Luis. 2006. "The 'Keen-Eyed Critic of the Ocean': James Fenimore Cooper's Invention of the Sea Novel." In James Fenimore Cooper Society Miscellaneous Papers 23: 1-7. James Fenimore Cooper Society Website. http://external.oneonta.edu/cooper/articles/ala/2006ala-iglesias.html.

Ignatiev, Noel. (1995) 2009. How the Irish Became White. Milton Park: Routledge.

Karl, Michaela. 2011. Die Geschichte der Franenbewegung. Stuttgart: Reclam.

Karremann, Isabel. 2011. “The Sea Will Make a Man of Him?' Hypervirility, Effeminacy, and the Figure of the Queer Pirate in the Popular Imagination from the Early Eighteenth Century to Hollywood." Historical Masculinities as an Intersectional Problem. Special issue, Gender Forum 32. http://genderforum.org/historical-masculinities-as-an-intersectional-pro blem-issue-32-2011/.

Kent, Holly M. 2008. “'Our Good Angel': Women, Moral Influence, and the Nation in Antebellum American Pirate Novels." Limina: A Journal of Historical and Cultural Studies 14: 50-58. http://www.archive.limina.arts.uwa. edu.au/_data/page/186594/Kent.pdf.

Leonard, Elizabeth D. 1999. All the Daring of the Soldier: Women of the Civil War Armies. New York: W. W. Norton.

Lewis, R. W. B. 1955. The American Adam: Innocence, Tragedy and Tradition in the Nineteenth Century. Chicago: University of Chicago Press.

Mackenthun, Gesa. 2000. "Postcolonial Masquerade: Antebellum Sea Fiction and the Transatlantic Slave Trade." In Early America Re-Explored: New Readings in Colonial, Early National, and Antebellum Culture, edited by Klaus Schmidt and Fritz Fleischmann, 537-567. New York: Peter Lang.

- 2004. Fictions of the Black Atlantic in American Foundational Literature. London: Routledge.

Madison, Robert D. 1996. "Cooper's 'The Wing-And-Wing' and the Concept of the Byronic Pirate." In Literature and Lore of the Sea, edited by Patricia Ann Carlson, 119-132. Amsterdam: Rodopi.

Manning, Susan. 1993. "Review of The Red Rover and Notions of the Americans: Picked Up by a Travelling Bachelor, by James Fenimore Cooper." The Review of English Studies 44 (175): 450-452. 
Mellen, Grenville. 1997. Review of The Red Rover. North American Review 27 (1828): 139-54. Reprinted in James Fenimore Cooper: The Critical Heritage, edited by George Dekker and John P. Williams, 141-147. London: Routledge.

McWilliams, John. 2004. New England's Crises and Cultural Memory: Literature, History, Politics, Religion 1620-1860. Cambridge: Cambridge University Press.

Morrison, Toni. 1992. Playing in the Dark: Whiteness and the Literary Imagination. Cambridge: Harvard University Press.

Neuburg, Victor E. 1983. The Popular Press Companion to Popular Literature. Bowling Green: Bowling Green State University Popular Press.

Paul, Heike. 2014. The Myths that Made America. Bielefeld: transcript.

Peck, H. Daniel. 1976. "A Repossession of America: The Revolution in Cooper's Trilogy of Nautical Romances." Studies in Romanticism 15 (4): 589-605.

Pfitzer, Gregory M. 2008. Popular History and the Literary Marketplace, 18401920. Amherst: University of Massachusetts Press.

Philbrick, Thomas. 1961. James Fenimore Cooper and the Development of American Sea Fiction. Cambridge: Harvard University Press.

Philbrick, Thomas, and Marianne. 1991. "Historical Introduction." In James Fenimore Cooper: The Red Rover, a Tale, edited by Thomas and Marianne Philbrick, xvii-xl. Albany: State University of New York Press.

Raphael, Ray. 2004. Founding Myths: Stories That Hide Our Patriotic Past. New York: New Press.

Rediker, Marcus. 1996. "Liberty Beneath the Jolly Roger: The Lives of Anne Bonny and Mary Read, Pirates." In Iron Men, Wooden Women: Gender and Seafaring in the Atlantic World, 1700-1920, edited by Margaret S. Creighton and Lisa Norling, 1-33. Baltimore: Johns Hopkins University Press.

Rennie, Neil. 2013. Treasure Neverland: Real and Imaginary Pirates. Oxford: Oxford University Press.

Reynolds, David S. 1988. Beneath the American Renaissance: The Subversive Imagination in the Age of Emerson and Melville. New York: Knopf.

Rogin, Michael Paul. (1979) 1985. Subversive Genealogy: The Politics and Art of Herman Melville. Berkeley: University of California Press.

Schneck, Peter. 2007. "The Laws of Fiction: Legal Rhetoric and Literary Evidence." European Journal of English Studies 11 (1): 47-63.

Smith, Henry Nash. (1950) 2009. Virgin Land: The American West as Symbol and Myth. Cambridge: Harvard University Press.

Stanley, Jo. (1995) 1996. Bold in Her Breeches: Women Pirates Across the Ages. London: Pandora.

Streeby, Shelly. 2002. American Sensations: Class, Empire, and the Production of Popular Culture. Berkeley: University of California Press. 
Thompson, D. W., and Merri Lou Schaumann. 1989. "Goodbye, Molly Pitcher." Cumberland County History 6 (1): 3-26.

Walker, Warren S. 1963. "Introduction." In The Red Rover, by James Fenimore Cooper, edited by W. S. Walker, iv-xvii. Lincoln: University of Nebraska Press. Wheelwright, Julie. 1994. Amazons and Military Maids: Women Who Dressed as Men in Pursuit of Life, Liberty and Happiness. London: Pandora.

- (1995) 1996. "Tars, Tarts and Swashbucklers." In Bold in Her Breeches: Women Pirates Across the Ages, edited by Jo Stanley, 176-200. London: Pandora.

Williams, Daniel E. 1983. "Rogues, Rascals and Scoundrels: The Underworld Literature of Early America." American Studies 24 (2): 5-19.

Woertendyke, Gretchen J. 2013. "Geography, Genre, and Hemispheric Regionalism." Atlantic Studies 10 (2): 211-227.

Young, Alfred Fabian. 1999. The Shoemaker and the Tea Party: Memory and the American Revolution. Boston: Beacon Press.

Young, Elizabeth. 1999. Disarming the Nation: Women's Writing and the American Civil War. Chicago: University of Chicago Press.

Open Access This chapter is licensed under the terms of the Creative Commons Attribution 4.0 International License (http://creativecommons.org/licenses/ by $/ 4.0 /$ ), which permits use, sharing, adaptation, distribution and reproduction in any medium or format, as long as you give appropriate credit to the original author(s) and the source, provide a link to the Creative Commons license and indicate if changes were made.

The images or other third party material in this chapter are included in the chapter's Creative Commons license, unless indicated otherwise in a credit line to the material. If material is not included in the chapter's Creative Commons license and your intended use is not permitted by statutory regulation or exceeds the permitted use, you will need to obtain permission directly from the copyright holder.

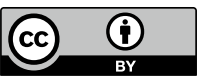

